مجلة تربويات الرياضيات

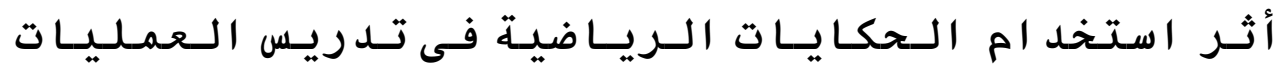

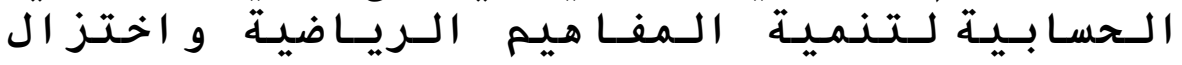

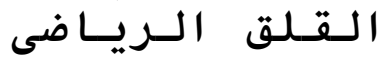

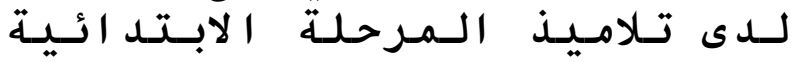

\author{
إعداد \\ د. يحيى زكريا صاوى إعاد \\ مدرس المناهج وطرق تلريس الرياضيات \\ كلية التربية - جامعة عين شمس تلرين الرياضيات
}




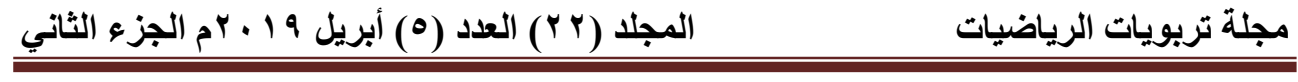

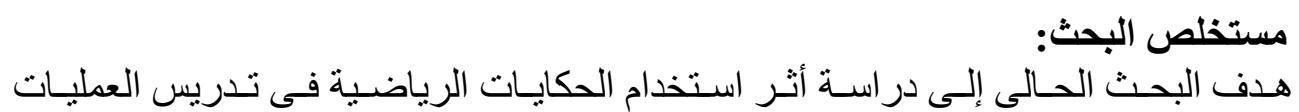

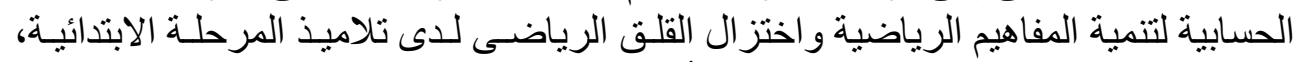

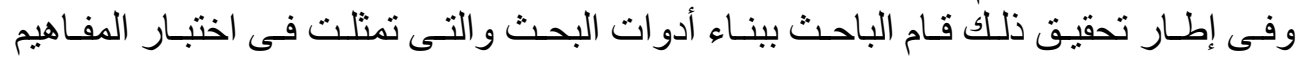

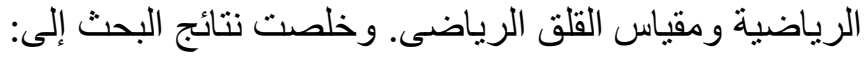

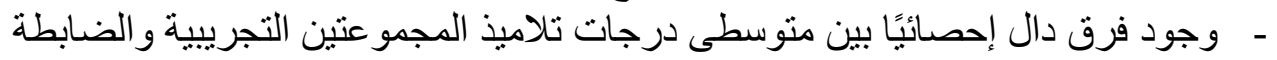

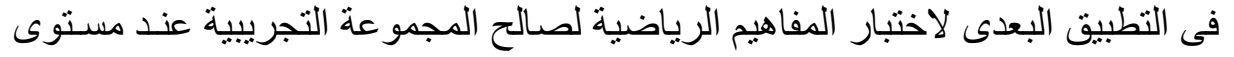

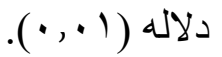

$$
\begin{aligned}
& \text { - وجود فرق دال إحصائيًا بين منوسطى درجات تلامبذ المجمو عنين التجريبية و الضابطة }
\end{aligned}
$$

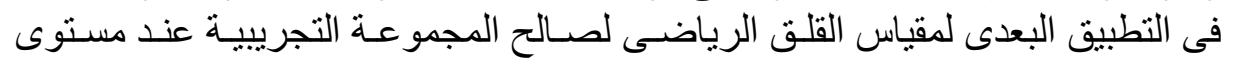

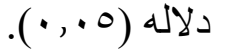

$$
\begin{aligned}
& \text { الكلمات المفتاحية: الحكايات الرياضية ـ المفاهيم الرياضية ـ القلق الرياضى. }
\end{aligned}
$$

\begin{abstract}
The current research aimed at investigating the effect of using mathematical tales in teaching mathematics to develop mathematical concepts and reducing the mathematical anxiety. In this context, the researcher designed the research instruments which represented in a mathematical concepts test and the mathematical anxiety scale. Results concluded that:

- There is a statistically significant difference between the mean scores of the students of experimental and control groups in the post-test for mathematical concepts for the experimental group at the level of 0.01 .

- There is a statistically significant difference between the mean scores of the students of experimental and control groups in the post-test for mathematical anxiety scale for the experimental group at the level of 0.05 .
\end{abstract}

Key words: mathematical tales - mathematical concepts Mathematical anxiety. 


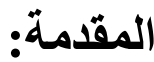

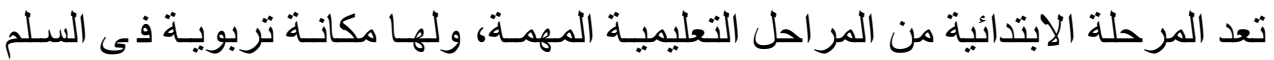

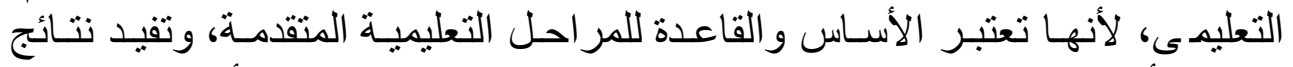

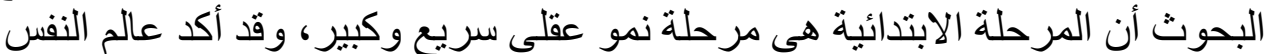

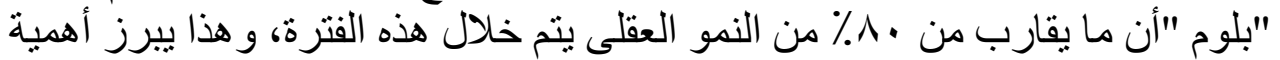

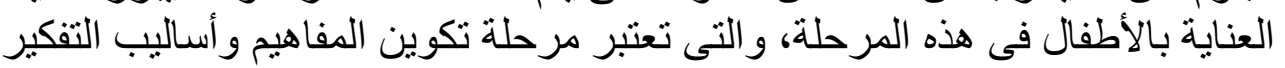

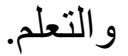

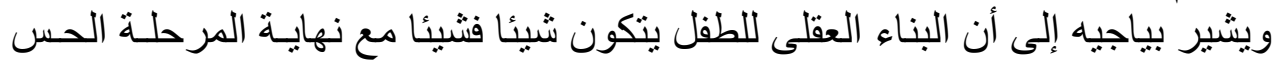

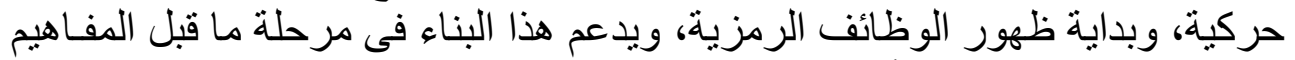

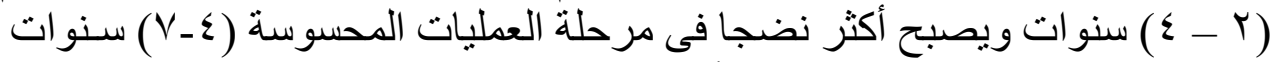

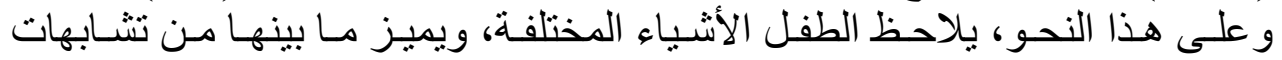

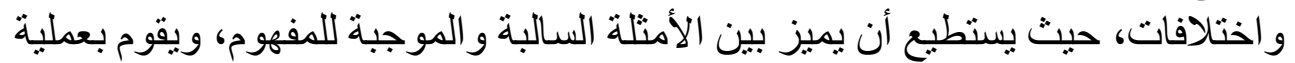

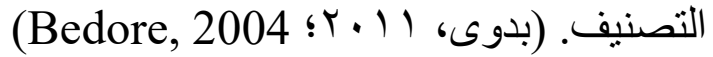

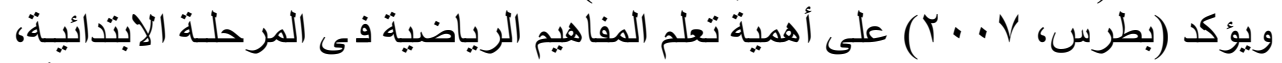

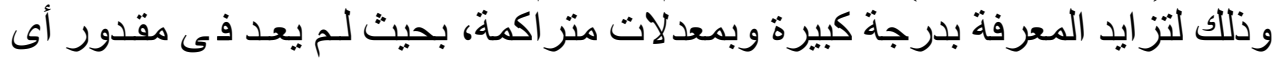

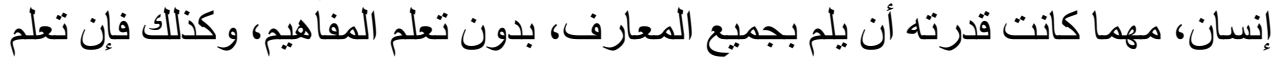

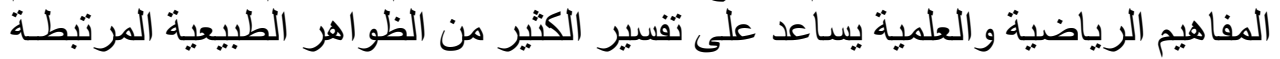

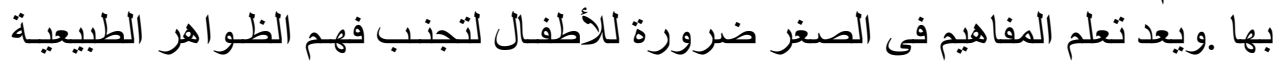

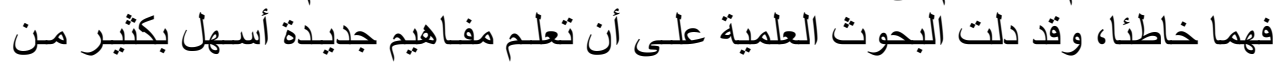
تصحيح مفاهيم خاطئة.

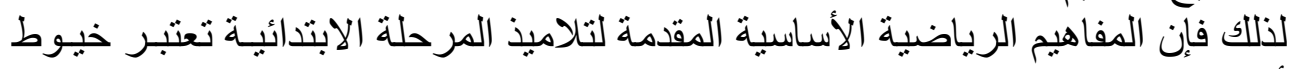

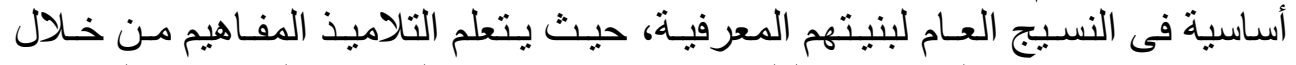

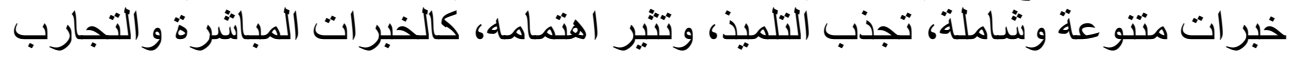

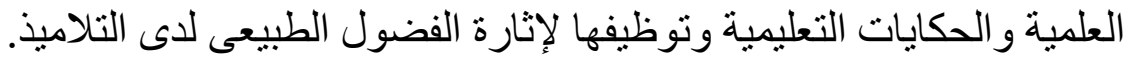

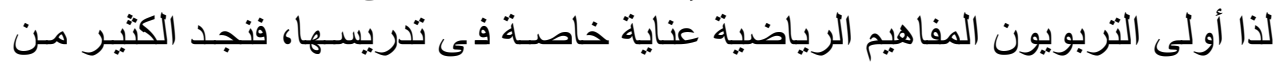

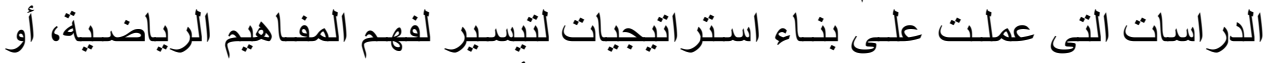

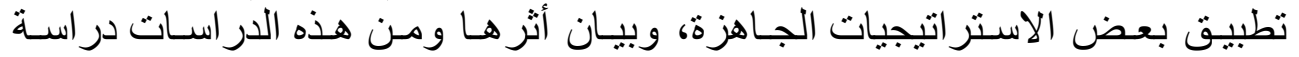

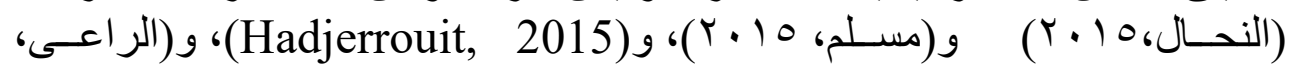
(Anglo and Iliev, 2012) (Y.)

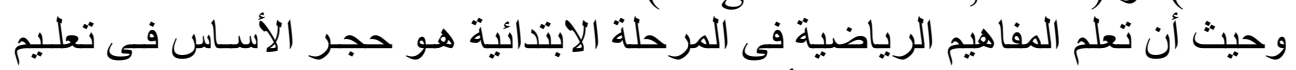

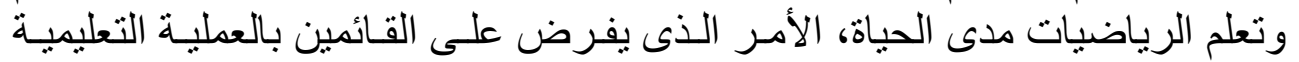


إعادة النظر فى طرق تدريس الرياضيات الحالية والبحث عن طرق و أساليب تدريسية

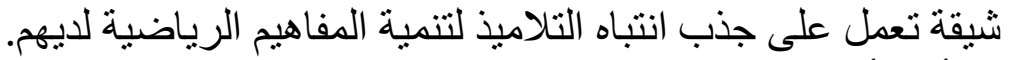

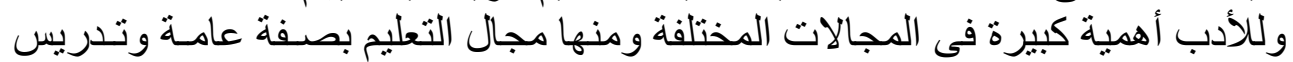

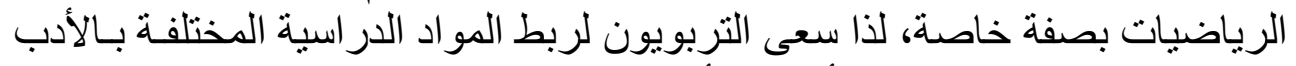

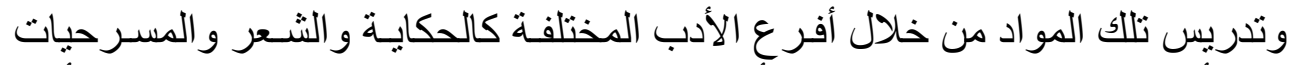

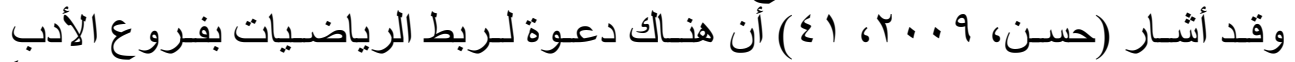

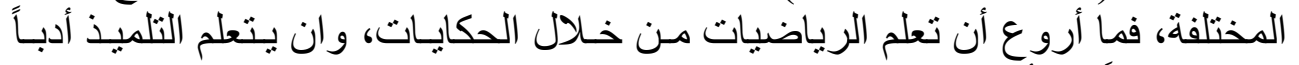

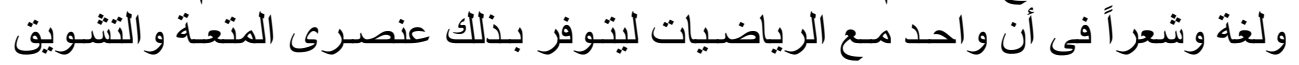

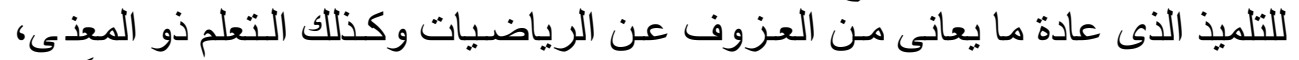

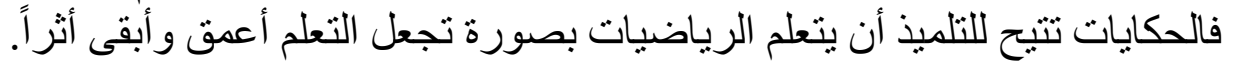

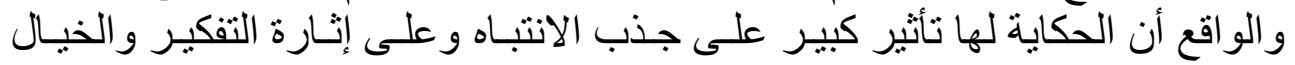

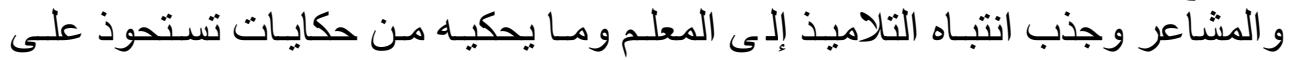

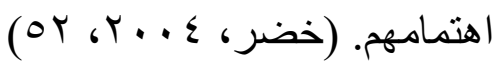

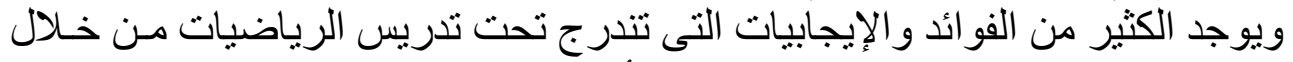

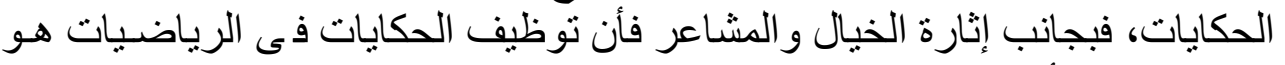

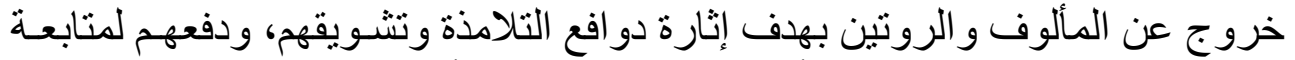

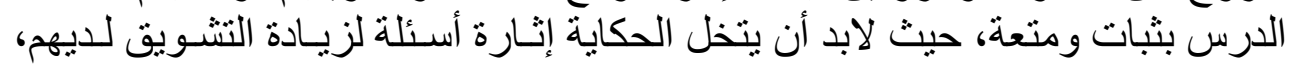

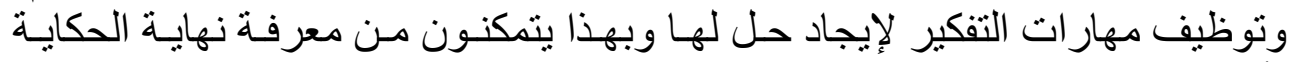

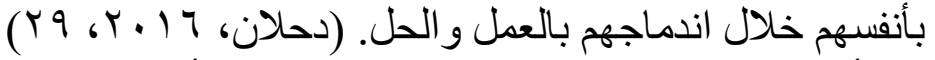

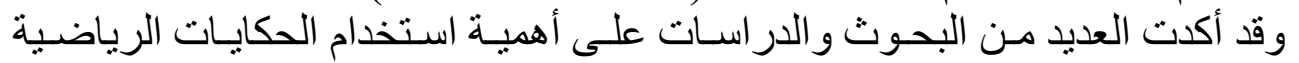

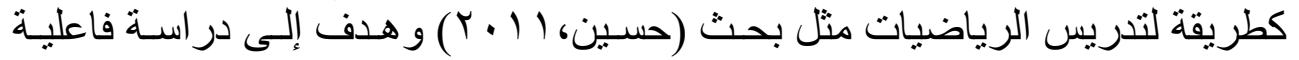

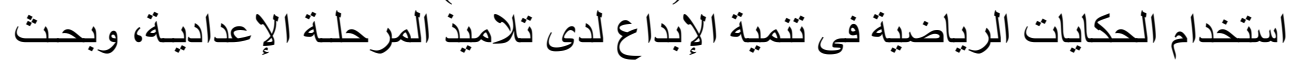

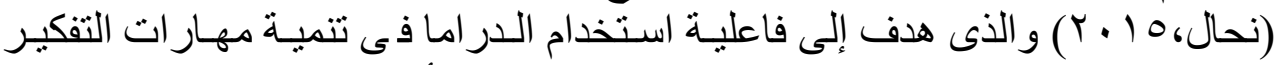

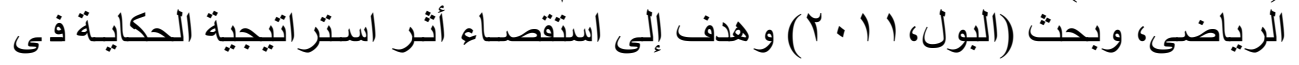

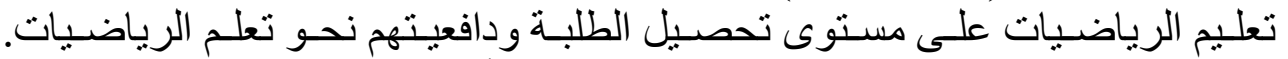

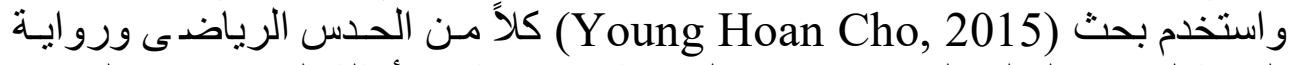
القصة لتحقيق التعليم الهادف وقدمت الدراسة مجمو عة من أمثلة القصص في المناهج

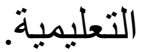
وتعد الرياضيات علم تجريديا من ابداع العقل البشرى يركز على طرق الحل و التفكير

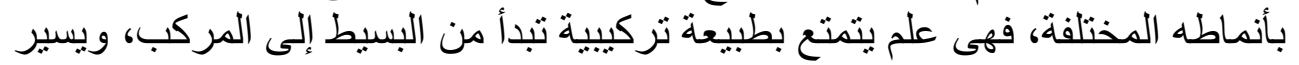

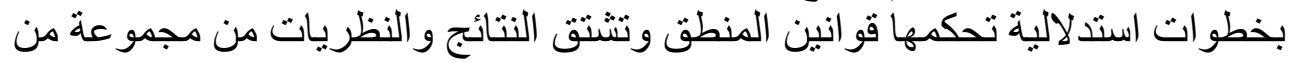

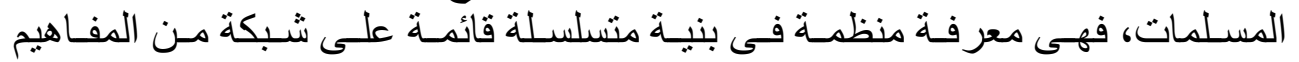


و التعمبيـات تـتلاحم فـى صـورة علاقـات وثيقـة تكسـبها قـوة التر اكيـب والاتسـاقات

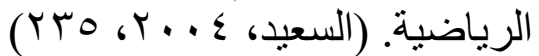

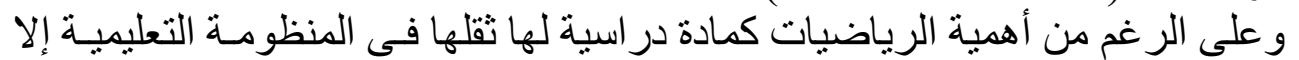

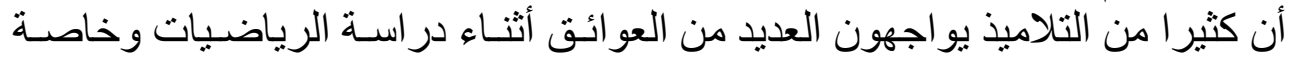

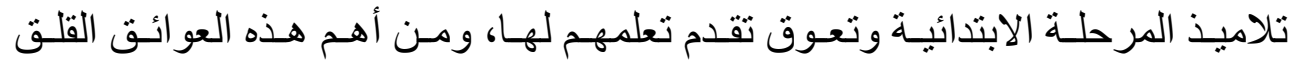

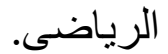

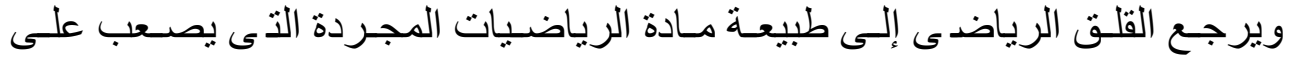

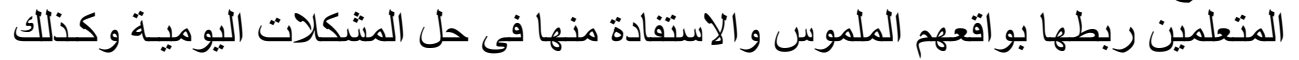

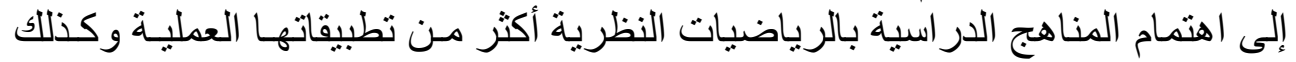

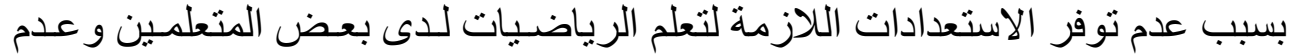

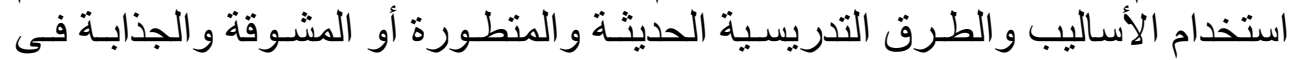
تدريس الرياضيات. وقد أكدت العديــ مـن البحـوث و الدر اسـات على أهميـة اسـتخدام المـداخل التدريسية

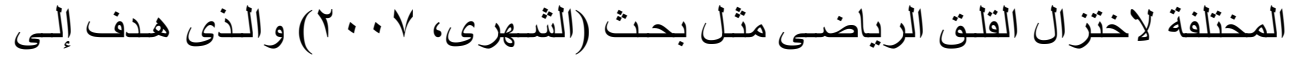

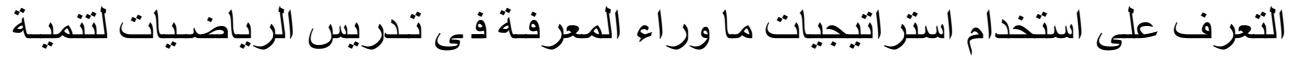

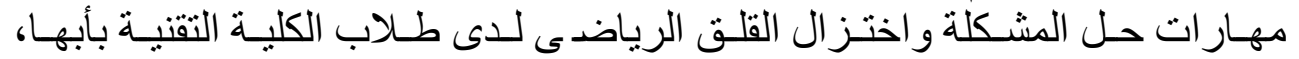

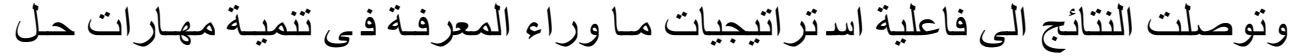
المشكلات و اختز ال القلق الرياضئ.

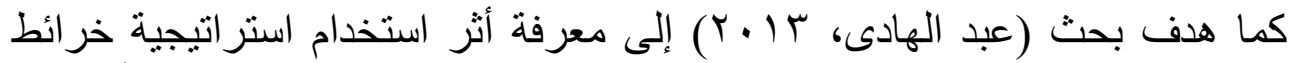

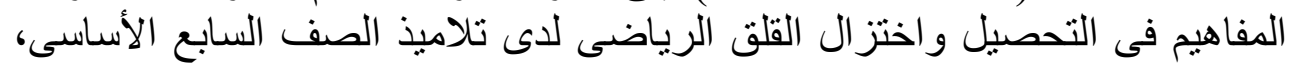

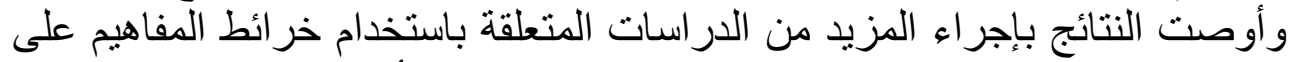

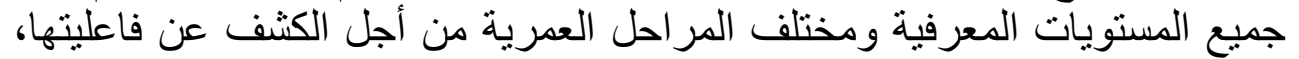
وتدريب المعلمين على استخدام استراتيجيات تدريس جديدة بما فيها استراتيجية

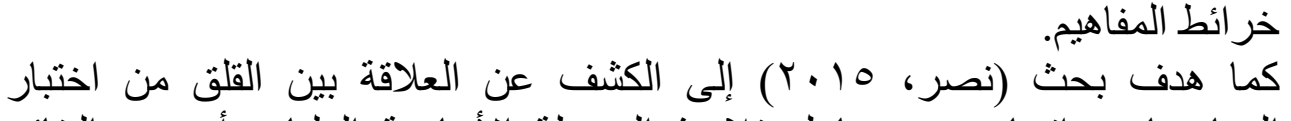

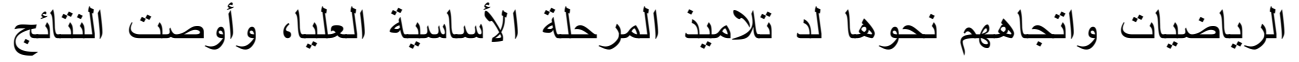

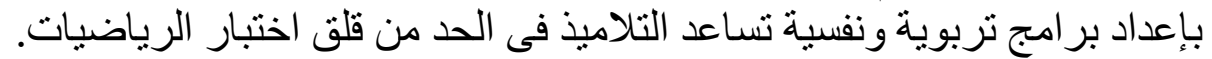

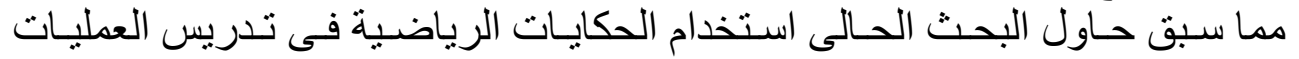

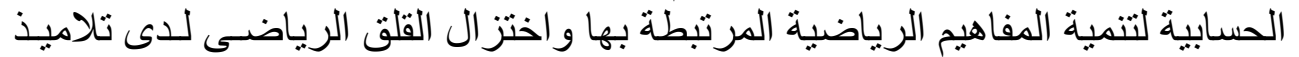
المرحلة الابتدائية. 


\section{مشكئة البحث:}

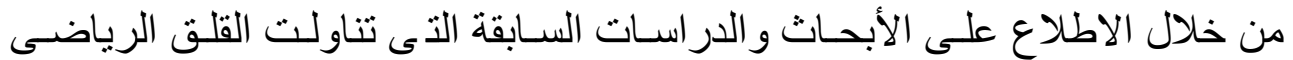

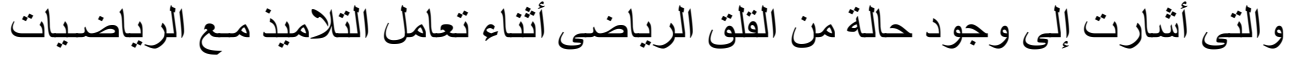

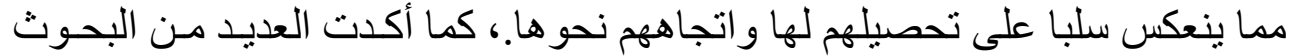

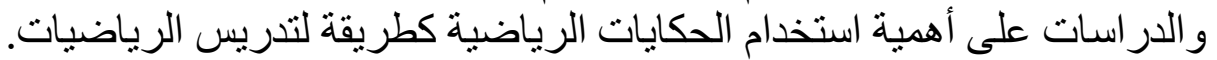

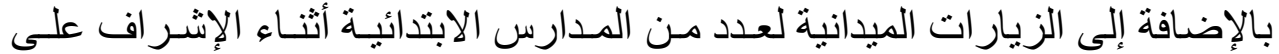

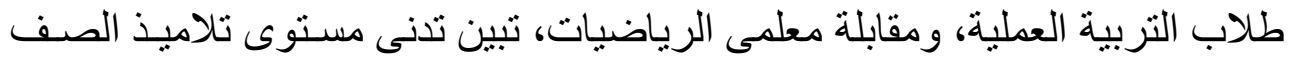

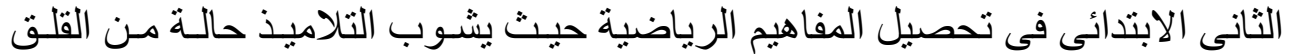

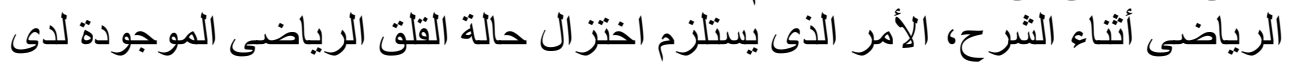

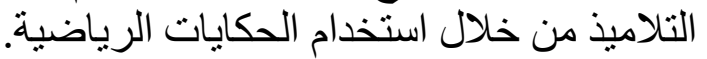

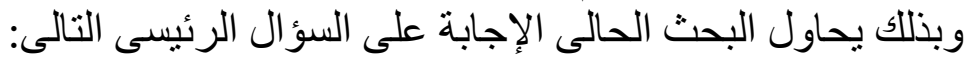

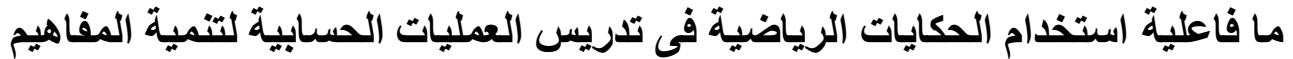
الرياضية واختزال القلق الرياضى لإى الرياضية تلاميذ المرحلة الابتدائية؟ ويتفرع من هذا السؤ ال الرئيسى الأسئلة التالية:

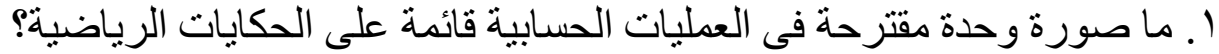

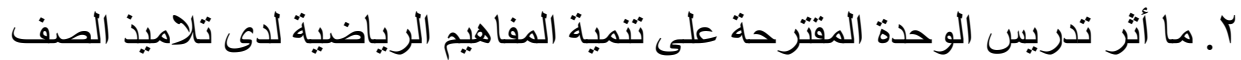

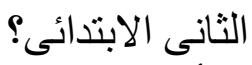

r. ما أثر تدريس الوحدة المقترحة على اختز ال القلق الرياضى لإى تلاميذ الصف

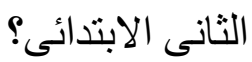

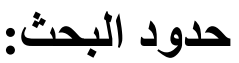

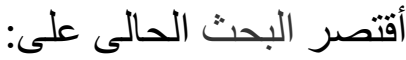

ا . عينة من تلاميذ الصف الثانى الابتدائى بمدرسة الطبرى الابتدائية بالقاهرة.

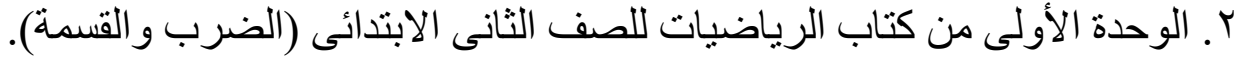

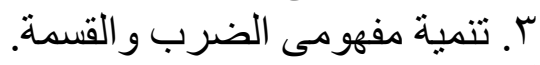

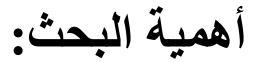
تظهر أهمية البحث الحالى بالنسبة لكل من:

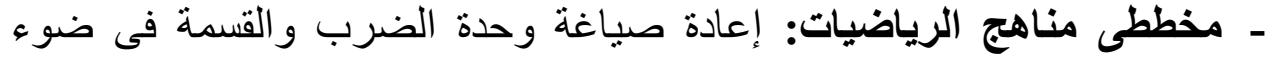

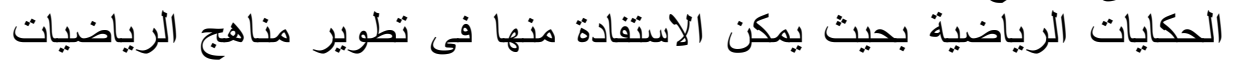
بالمرحلة الابتدائية. 
- معلمى الرياضيات: يوجه هذا البحث الأنظار إلى أهمية استراتيجية الحكاية فى الرئية

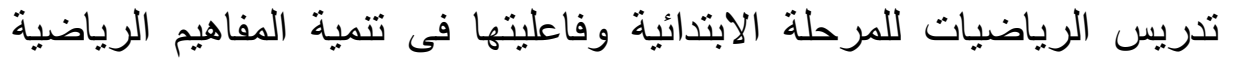

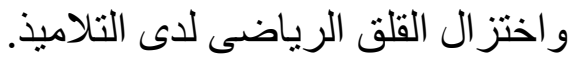
- الباحثين: تقديم رؤية جديدة لاستر اتيجيات التنديس الثيقة و البعيدة عن الروتين، ومن ثم يفتح لهم الأفاق فى مجال طرق التئن التدريس. فروض البحث:

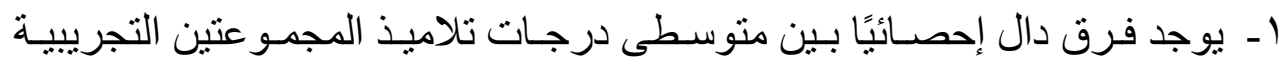

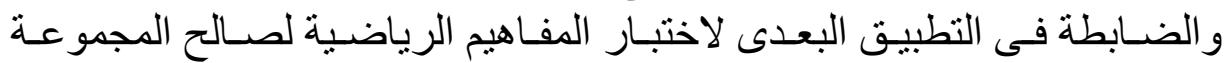

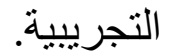

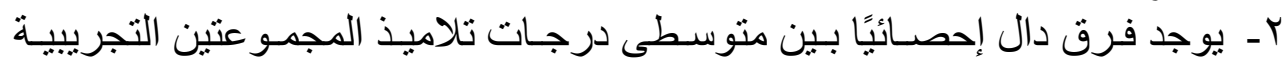

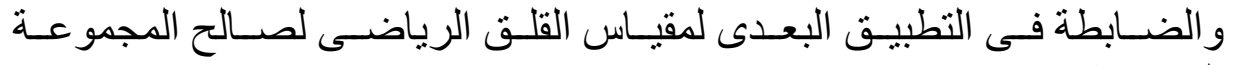

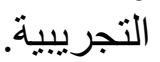
مصطاحات البحث:

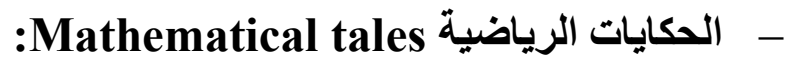

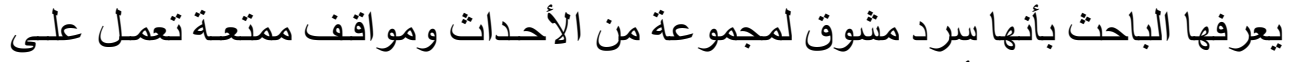

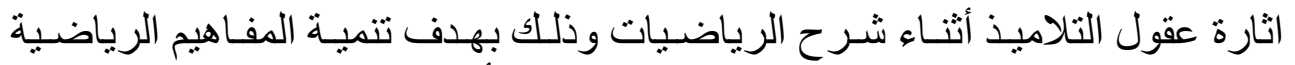
واختز ال حالة القلق الرياضى التى يشعر بهاء التهاء التلاميذ أثناء التعامل مع الرياضيات.

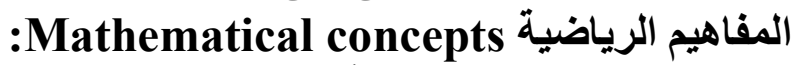

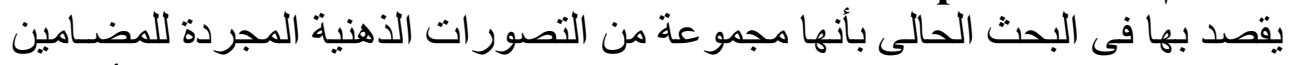

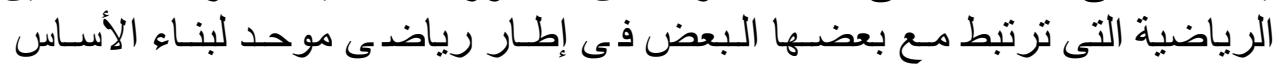

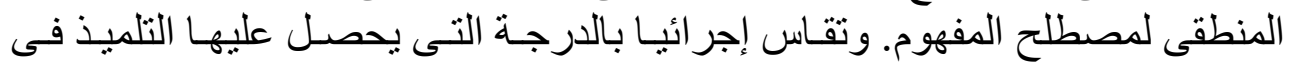

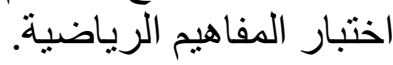
القلق الرياضى Mathematical anxiety: يقصد بالقلق الرياضى فى هذا البحث: " حالة انفعاليه تصيب تلميذ المرحسئلة الابتدائية

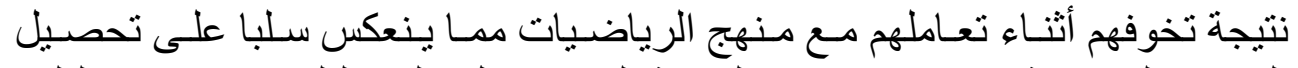
الرفاهيم الرياضية، وتقاس إجر ائيا بالدرجة التى يحصل عليها التياتيات التلميذ فى مقياس القلق تلقيل

$$
\text { إجراءاتى البحث: }
$$

سار البحث الحالى وفق الخطوات التات التالية:

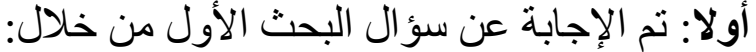

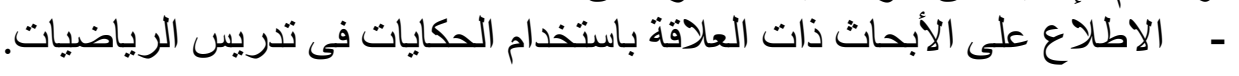




$$
\text { - - مديد أهداف الوحدة المقترحة. }
$$

- إعادة صياغة محتوى وحدة الضرب و والقسمة للصف الثانى الابتدائى فى ضـوء مدخل الحكايات.

- تحديد الأنشطة المنضمنة فى الوحدة المقترحة.

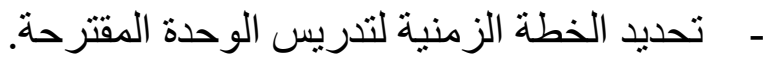

- تحديد استر اتيجيات تدريس الوحدة المقترحة.

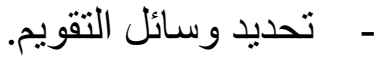

ثانيا: تم الإجابة عن سؤ الى البحث البحث الثنانى و الثالث من خلال:

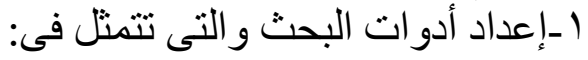

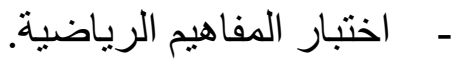

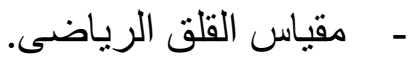

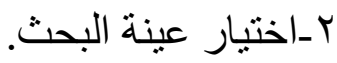

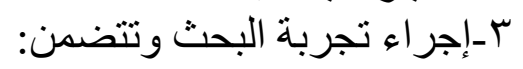

- تدريس الوحدة المقترحة للمجمو عة التجريبية.

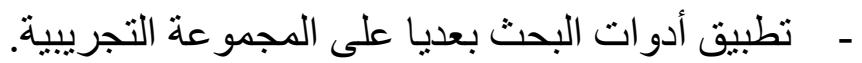

ثالثا: جمع البيانات ومعالجتها إحصائيا.

رابعا: تفسير النتائج ومناقتشتها.

خامسا: اقتراح التوصيات و البحوث المستقبلية.

\section{الإطار المعرفى للبحث}

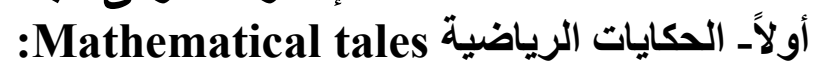

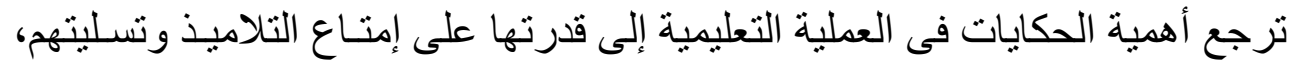

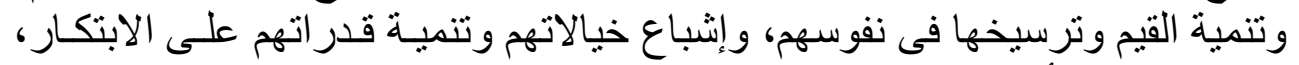

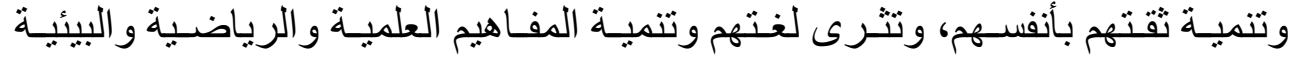

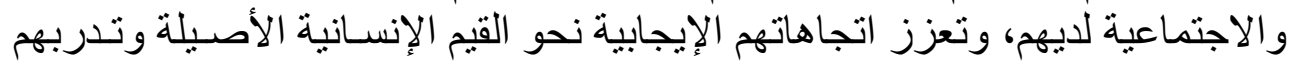

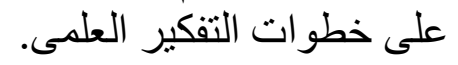
الحكايات وتلدريس المفاهيم الرياضيات:

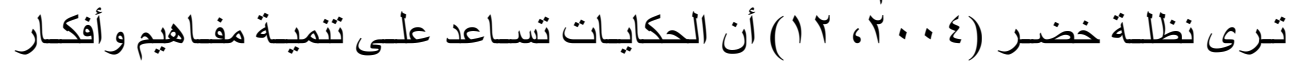

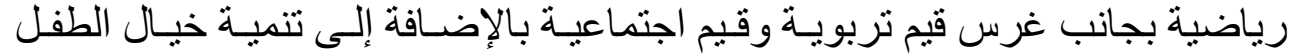

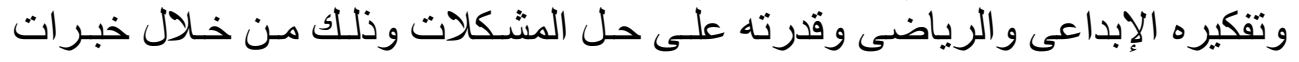


وأنشطة ثقافية ممتعة تتضمن معلومـات تغذذي حب استطلاع الطفل لمـا حولـه ومـا

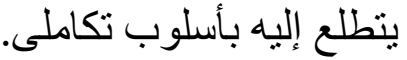

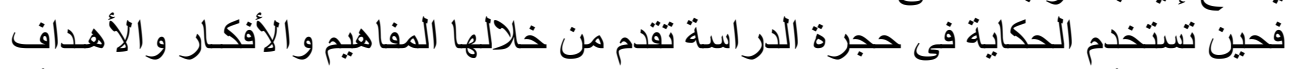

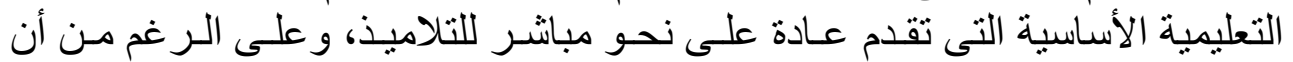

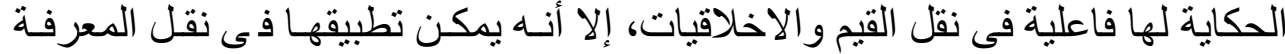

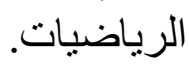

كما يرى المفتى أن من أهداف تدريس الرياضيات أن يتعرف التلميذ على الرياضيات

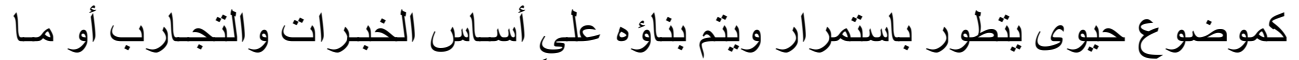

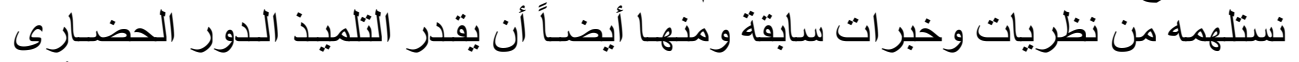

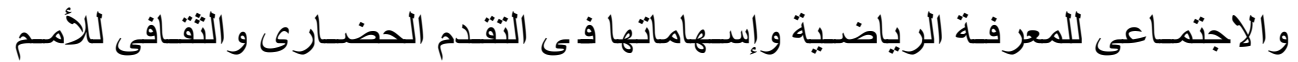

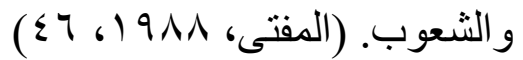

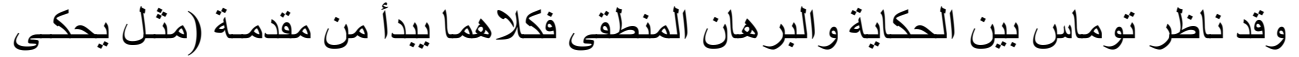

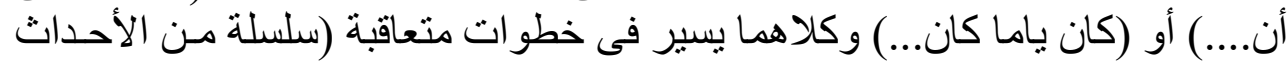

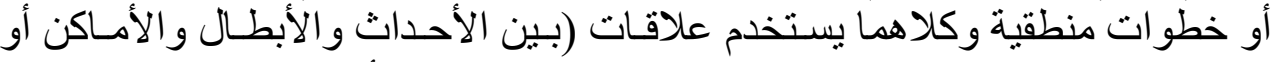

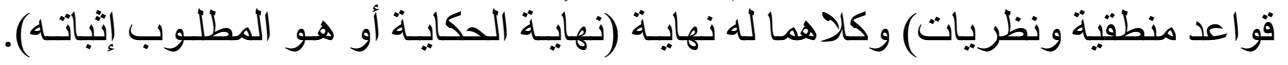

(Thomas , 2002, 46)

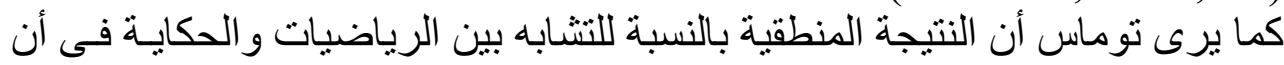

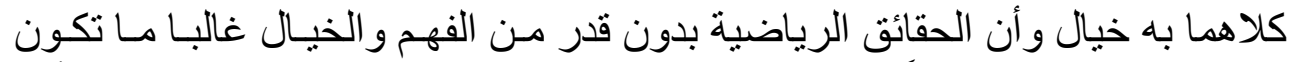

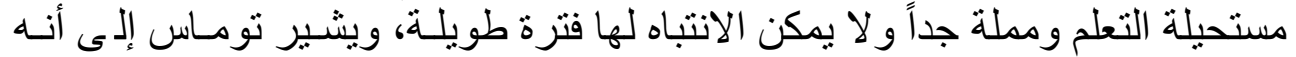

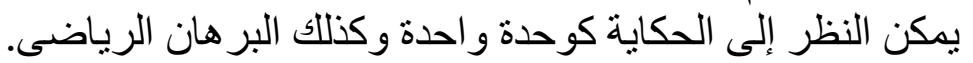
ويرى البحث الحالى أن توظيف الحكايات فى تعليم الرياضيات يداعم هدفين أساسيين

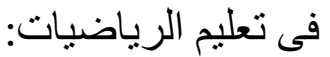
أو لاً: ربط الرياضيات الرياض داخل حجرة الدر اسة بالأنشطة الحياتية خارجها.

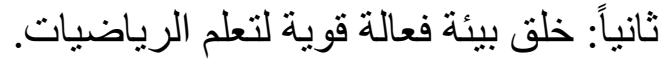

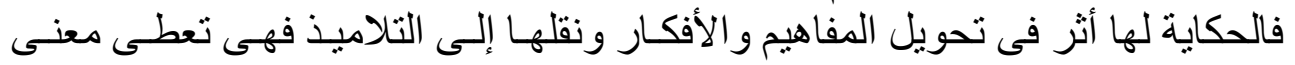

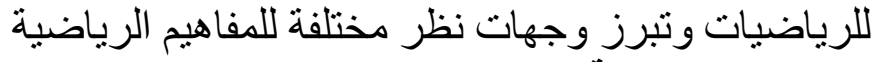
الحكايات الرياضية والقلق الرياضى:

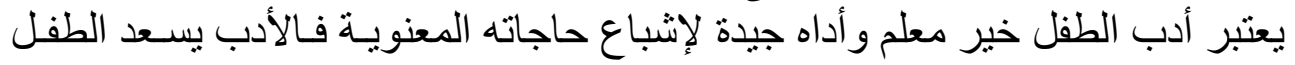

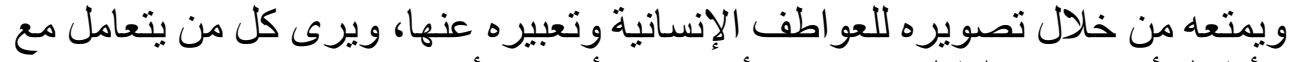

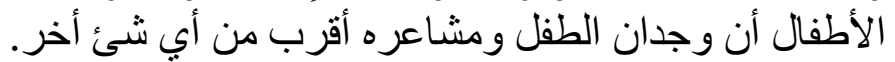

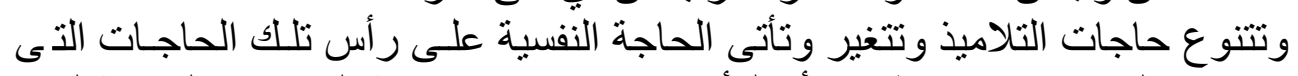

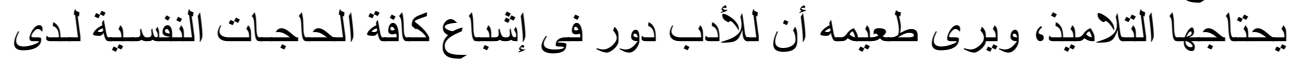


الأطفال بدءاً من الحاجة إلى الأكـن، التى تقف على على رأس الحاجـات النفسية للكـائن

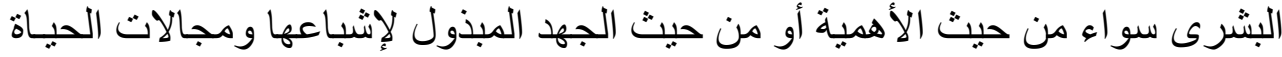

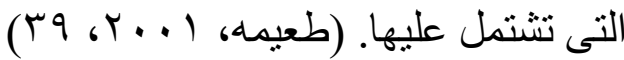

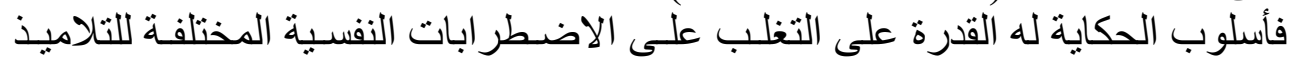

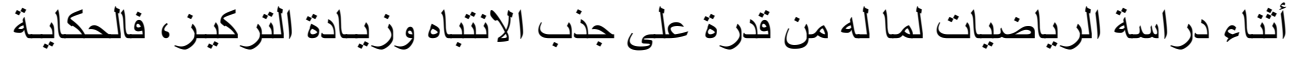

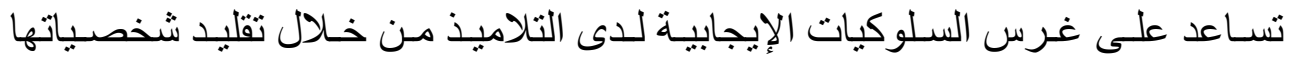

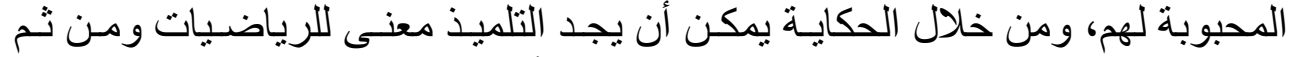

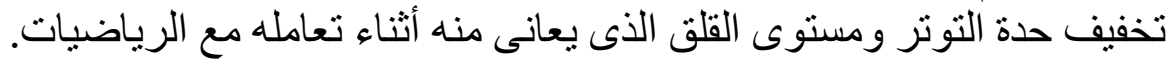

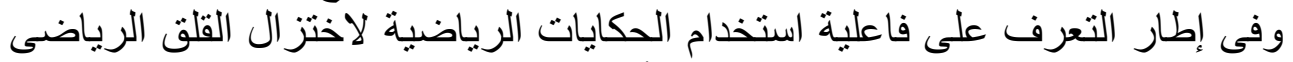

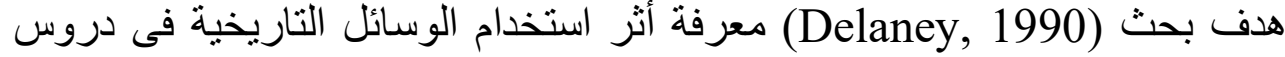

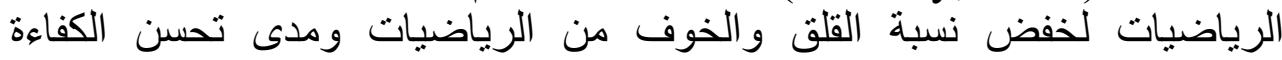

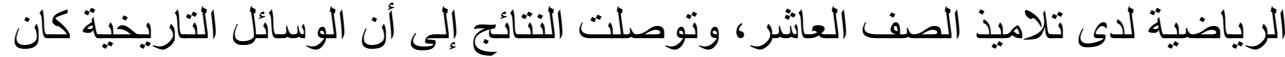

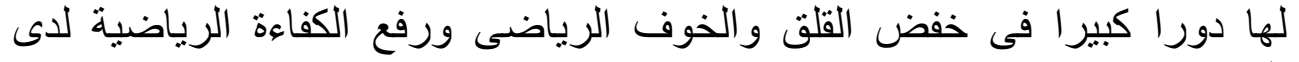

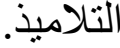

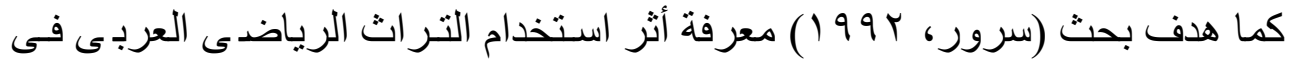

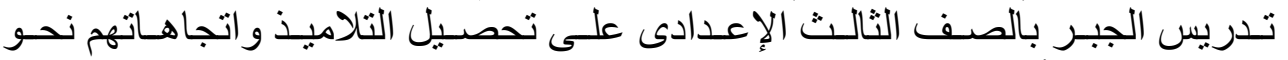

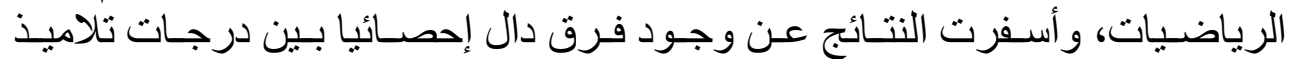

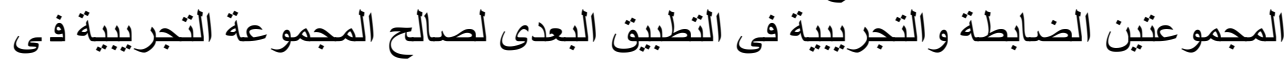
كل من تحصيل التلاميذ واتجاهاتهم نحو الرياضئ فياضيات.

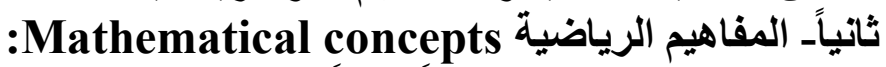

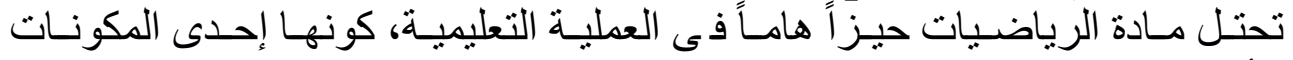

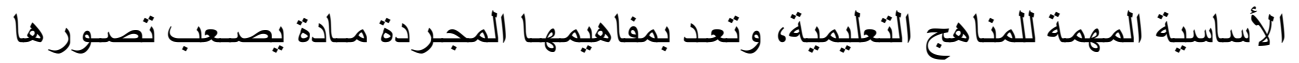

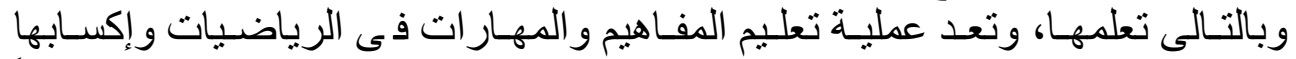

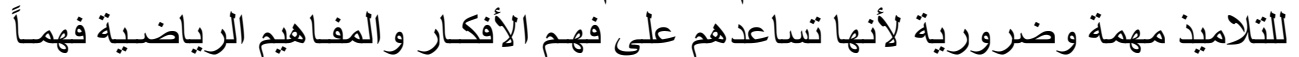
و واعياً.

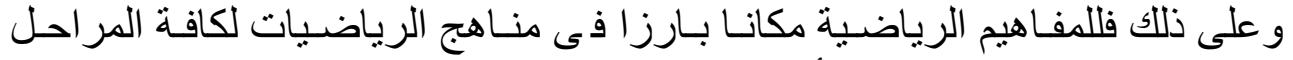

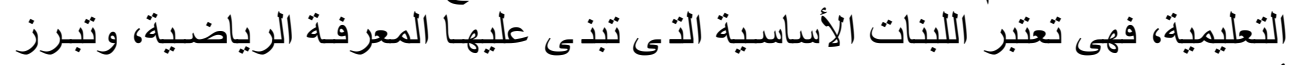

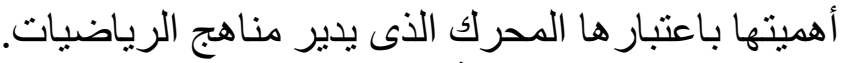
تعريف المفاهيم الرياضية:

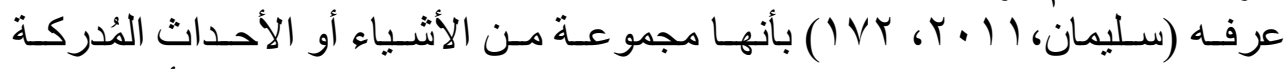

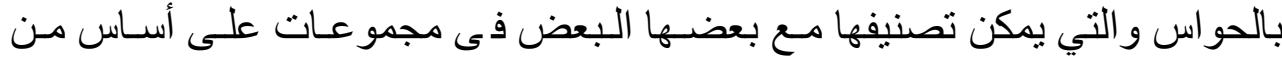

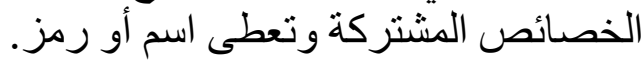




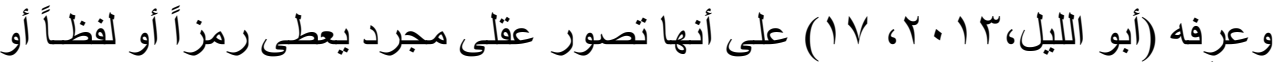

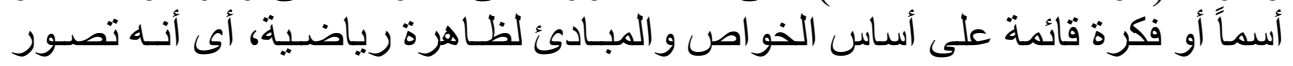

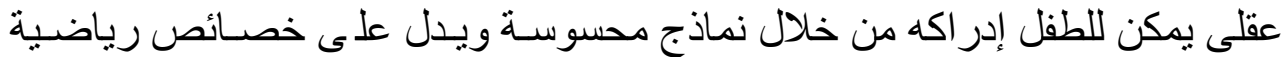

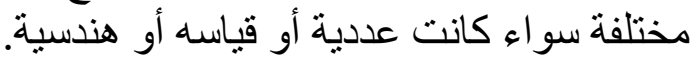

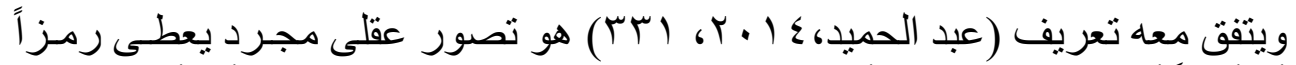

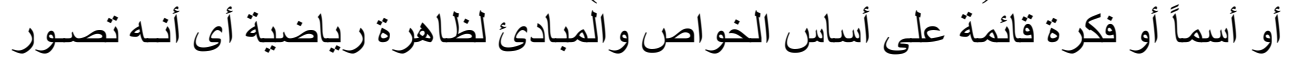

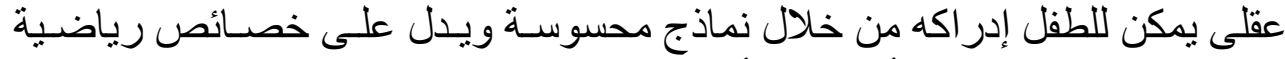

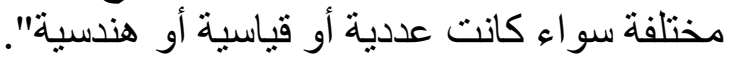

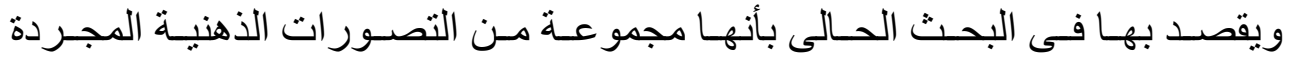

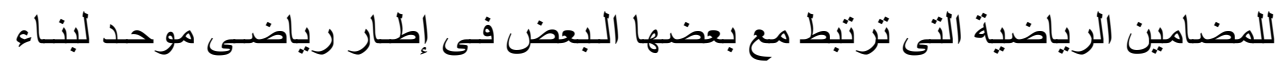
الأساس المنطقى لمصطلح المفهوم. وتقاس إجر ائيا بالدرجة التى التى يحصل عليها ريأيا التلميذ في اختبار المفاهيم الرياضية.

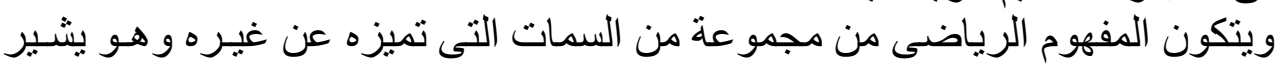

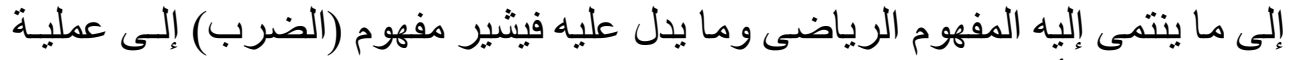

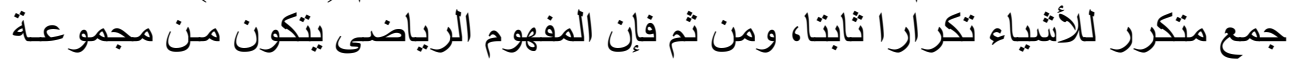

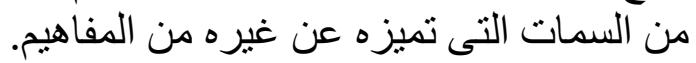

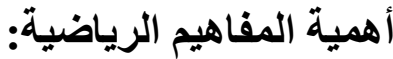

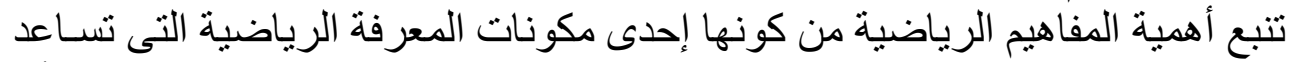

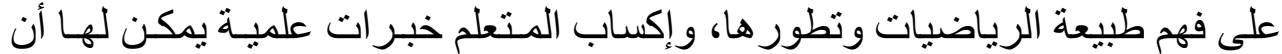

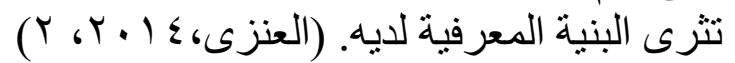

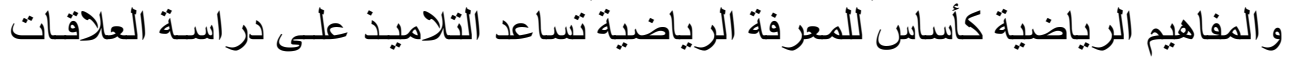
التى بينها وبالتالى فهم التعميمات الرياضئ الرياضية.

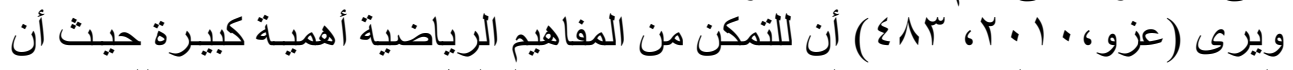

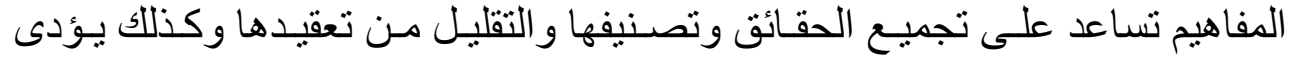

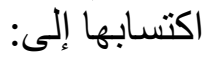
ا ا ـ تنمية المهار ات العقلية مثل التنظيم و الربطو التميز وتحديد الخصائص المشتركة.

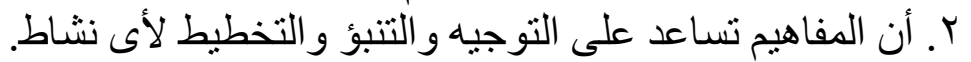

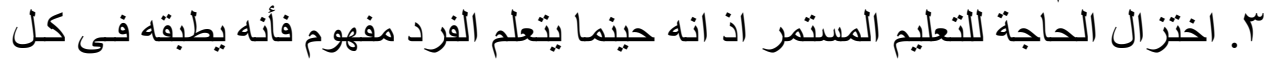

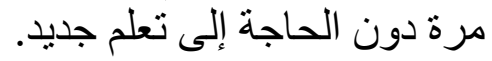
ع. اختز ال الكلمات اللغوية ذات الئ المعانى المحددة. ه. إثراء البناء المعرفى للتلميذ. 7. تساعد على تنظيم الخبرات العقلية. 
V. حل المشكلات باستخدام المفـاهيم و الربط بينهمـا و إعـادة تنظيمها أثنـاء وضـع

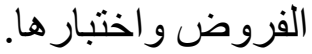

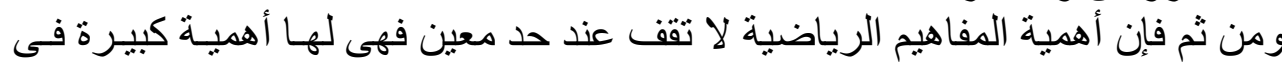

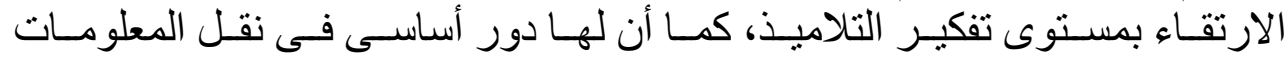

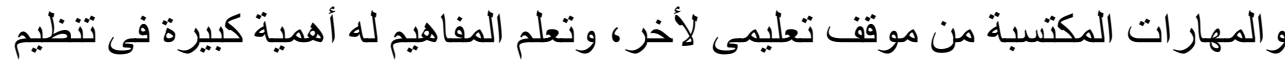

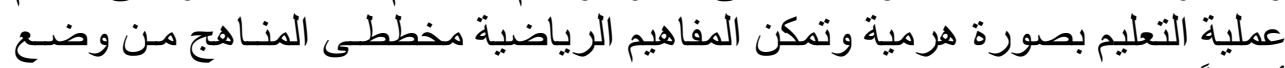
أساساً صحيحا لاختيار الخبر ات ات التعليمية وتنظيمها.

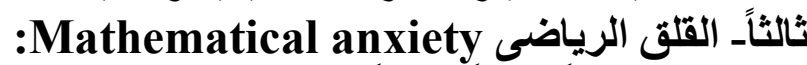

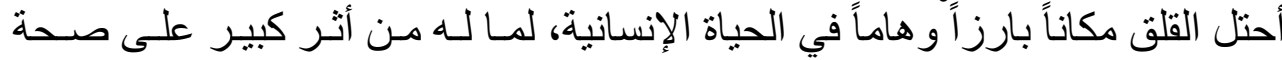

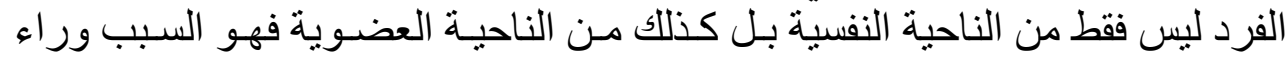

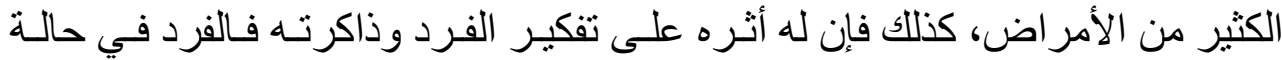

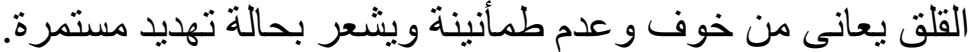

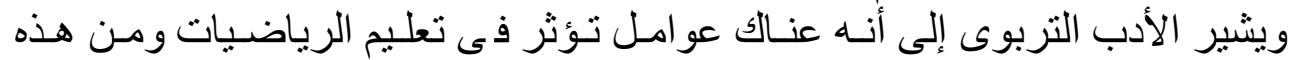

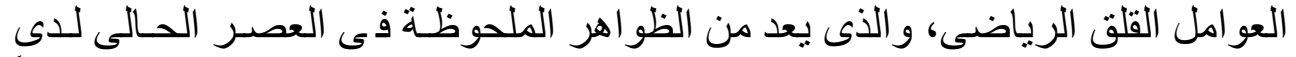

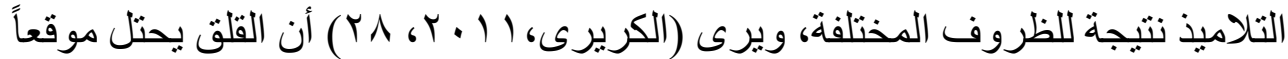

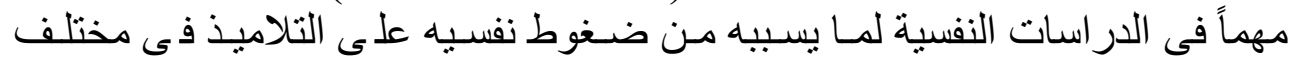

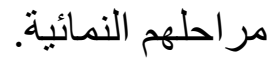

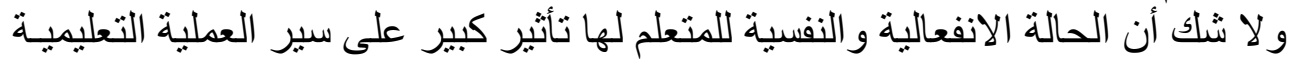

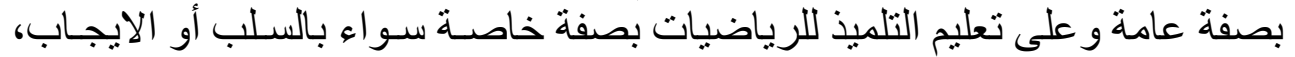

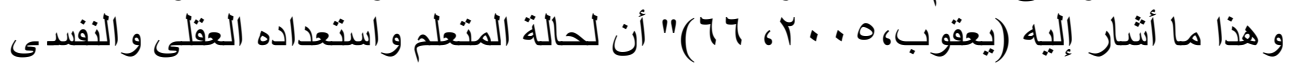

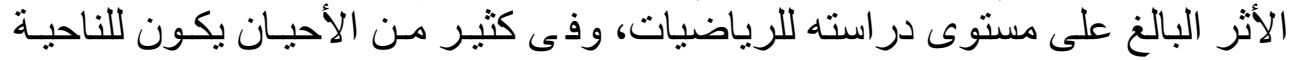

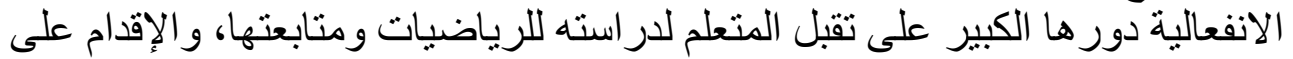

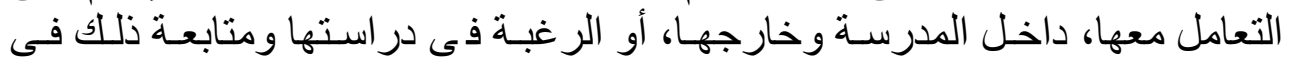

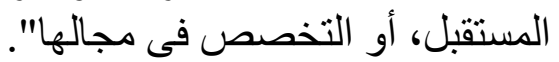

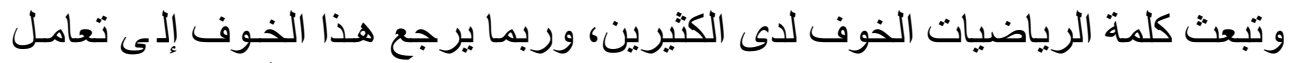

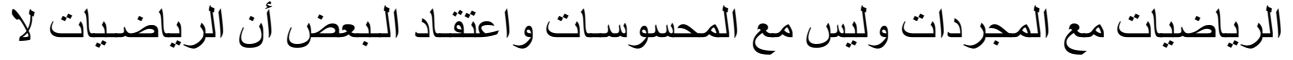

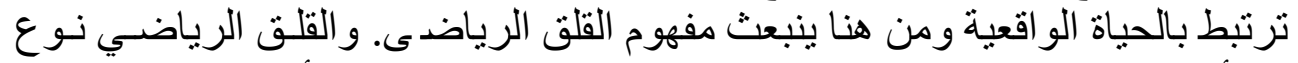

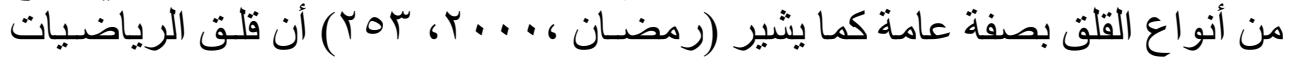

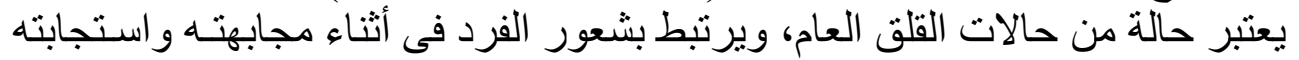

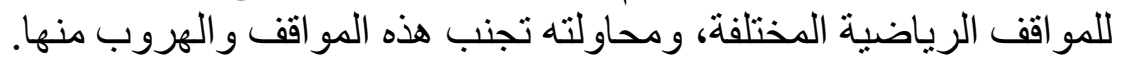




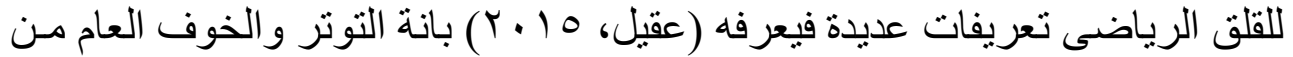

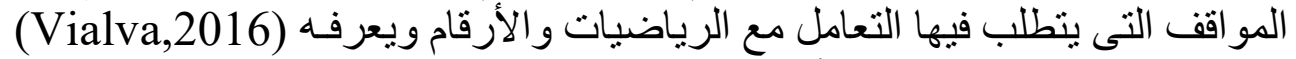

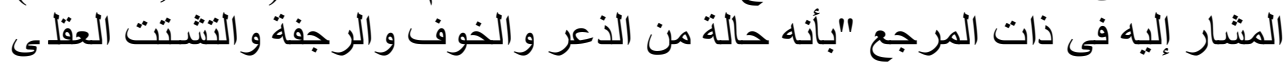

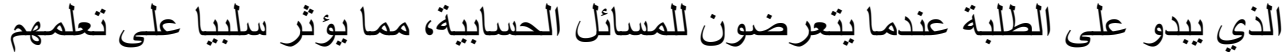
وتحصيلهم الأكاديمى.

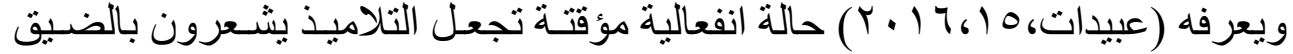

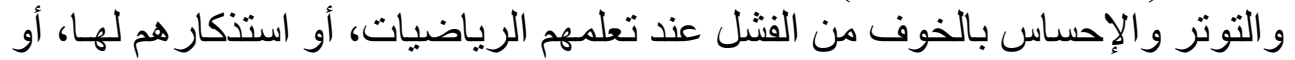

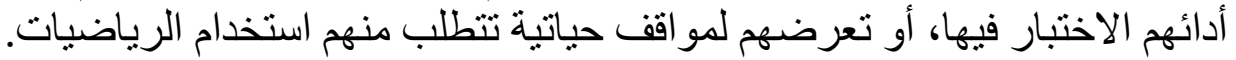
و عرفه البحث الحالى على أنه حالة انفعاليه تصيب تلميذ الميذ المرحلة الابتدائية نتيجة

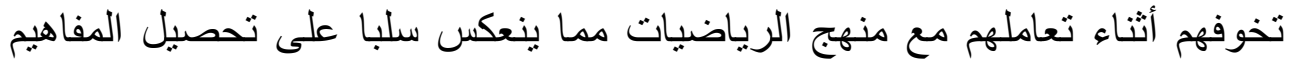
الرياضية، وتقاس إجرائيا بالدرجة التى يحصل عليها التياتيات التلميذ فى مقياس القلق علاقة القلق بالتحصيل الرياضى:

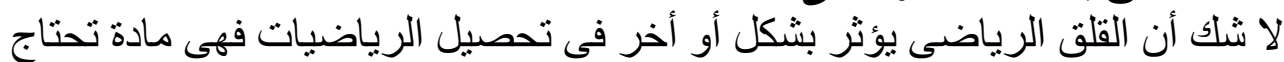

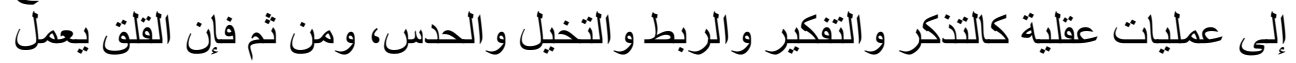

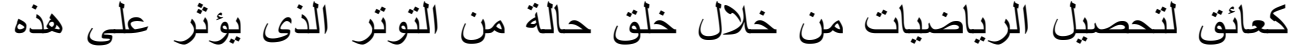

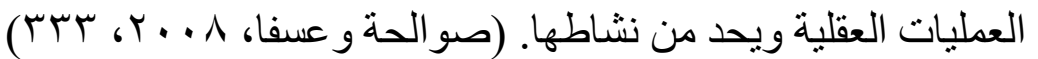

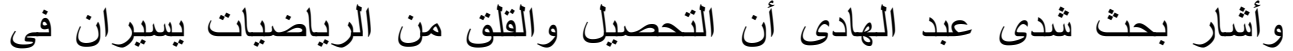

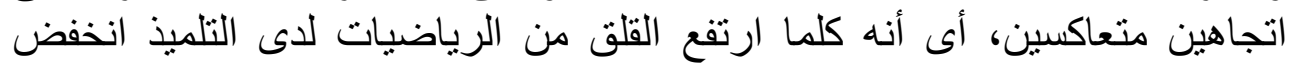

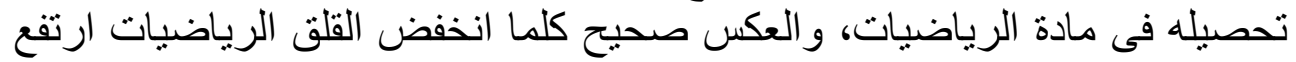

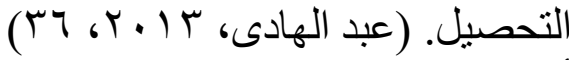

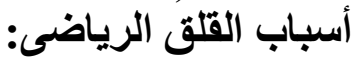
تتعدد الأسباب المؤدية إلى القلق الرياضى فبينما برئ البرى البعض أن القلق يعود إلى المادة

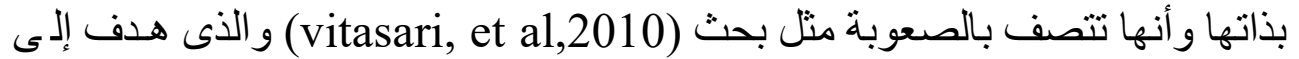

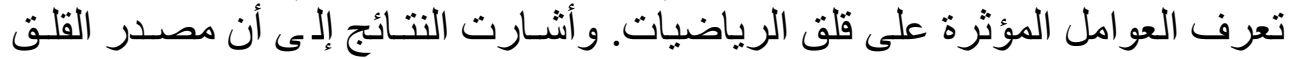

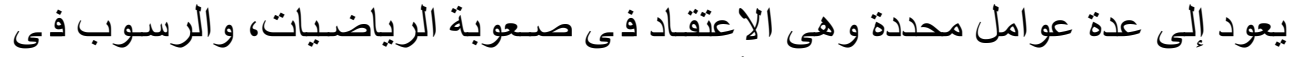

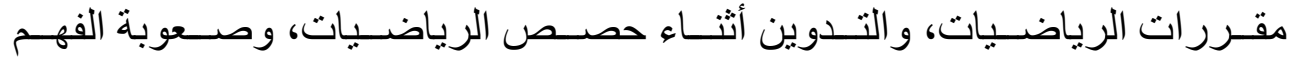

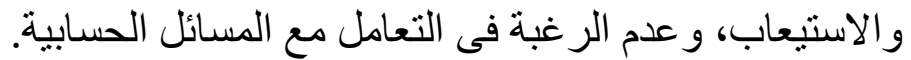

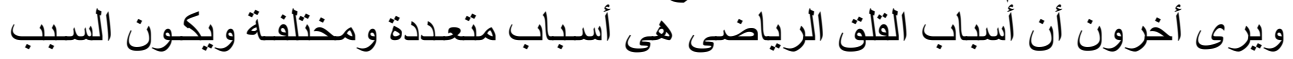

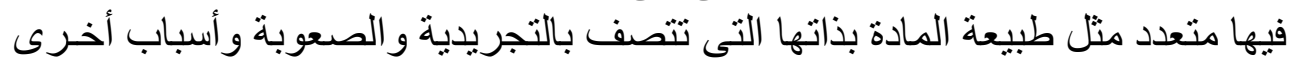
تقف على المعلم الذى لا يستخدم استر اتيجيات تعليمية قادرة على التى إخر اج التلميذ مـن 


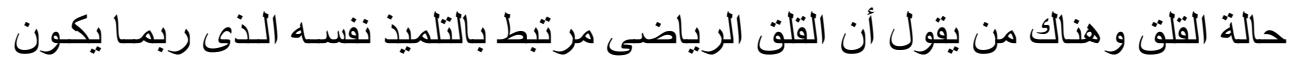

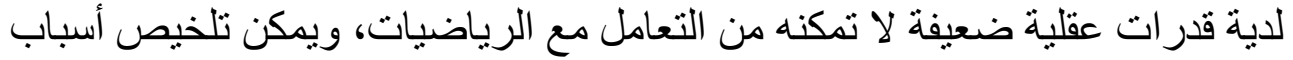

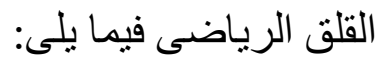
1 - صعوبة مادة الرياضيات وتميز ها بالجفاف و عدم ربطها بمو اقف الحياة.

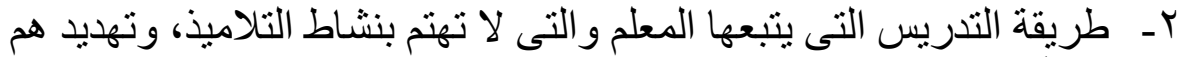

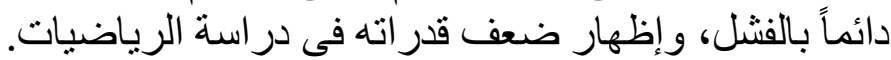

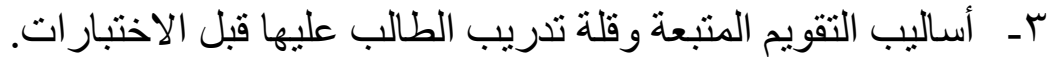

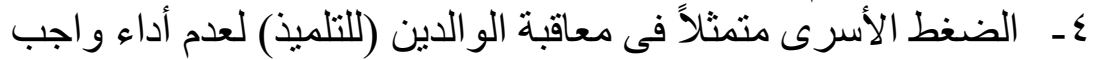

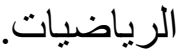
0ـ سلوك التلميذ نفسه في توقع الفنشل وبالتالى محاولة الابتعاد و الهروب من

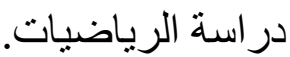
7- ضعف قدرات التلميذ وبالتالى انخفاض تحصيله فى الرياضيات.

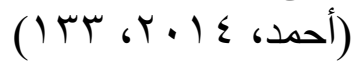

\section{الإطار التجريبى للبحث}

أولا: إعداد الوحدة المقترحة: أسس بناء الوحدة المقترحة:

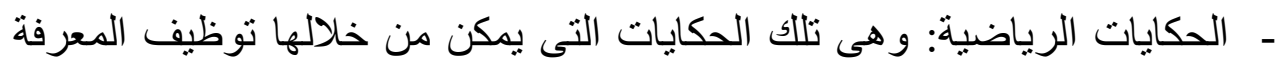

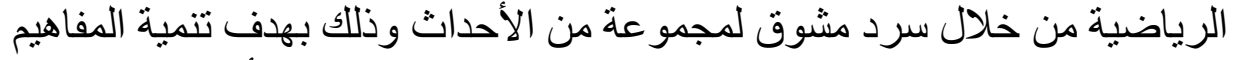

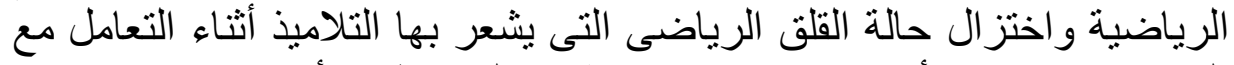

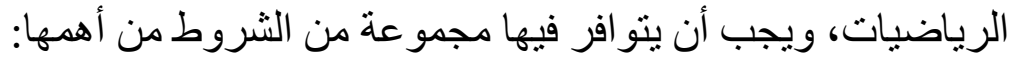

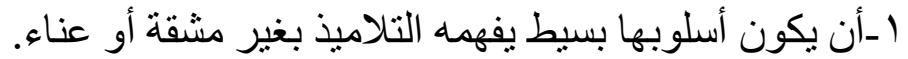

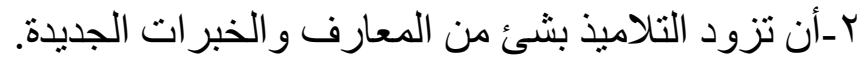

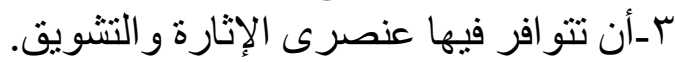

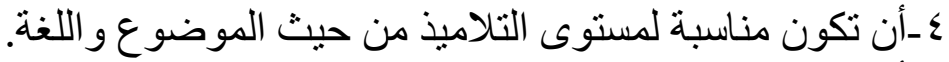

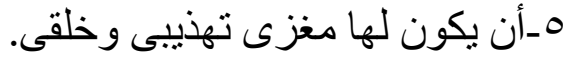

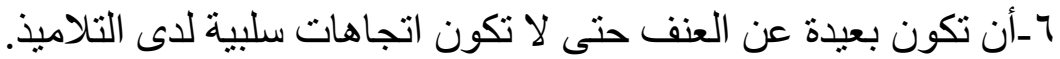

الأهداف العامة لتدريس مادة الرياضيات فى المرحلة الابتدائية:

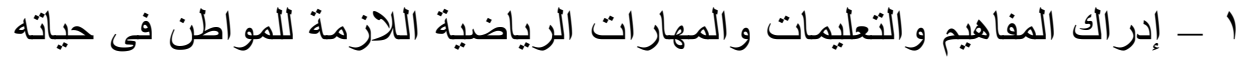

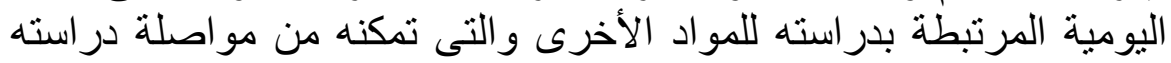

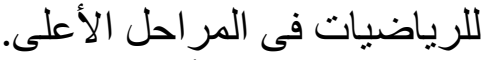
r - قراءة وكتابة الأعداد الطبيعية وتوظيفها فى الموافيات العق الحياتية وإجراء

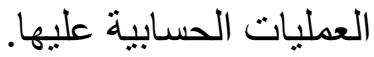


r- قر اءة وتفسير البيانات فى صور ها المختلفة.

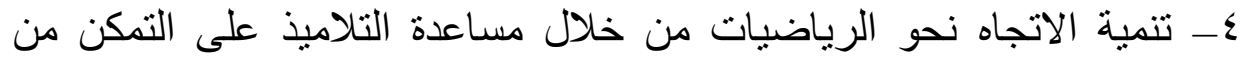

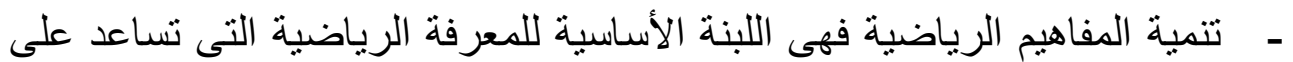
فهم طبيعة الرياضيات واستيعابها فى المر احل التعليمية المتقدمة.

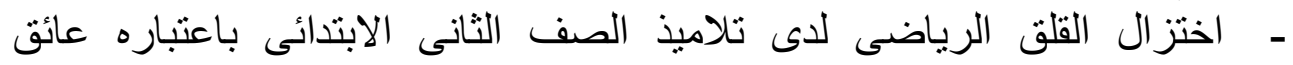
لتحصيل الرياضيات من خلال خلق حالة من التوتر التى تؤثر على هذه العمليات

$$
\text { العقلية ويحد من نشاطها. }
$$

محتوى الوحدة: تتكون الوحدة من ستة دروس، وهن وهم كالتالى: جدول (1): الخطة الزمنية لتدريس دروس الورسن الوحدة المقترحة

\begin{tabular}{|c|c|}
\hline محتوى & الدروس \\
\hline معنى عملية الضرب & الارس الأول \\
\hline خواص عملية الضرب & الارس الثانى \\
\hline جدول الضرب حتى جدول • & الدرس الثالث \\
\hline معنى عملية القسمة & الارس الرابع \\
\hline ايجاد خارج القسمة & الارس الخامس \\
\hline العلاقة بين الضرب والقسمة & الارس السادس \\
\hline
\end{tabular}

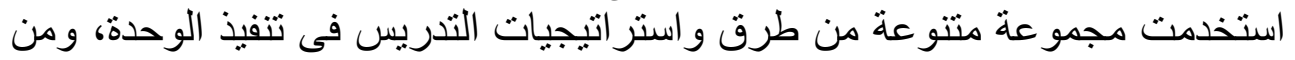

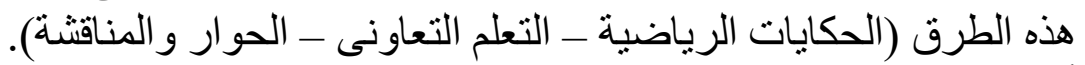

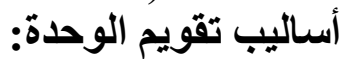

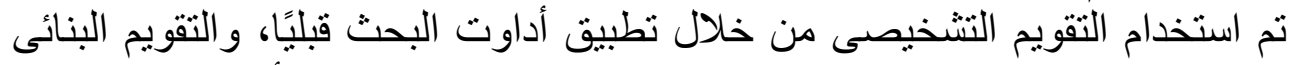

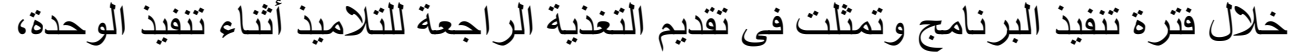

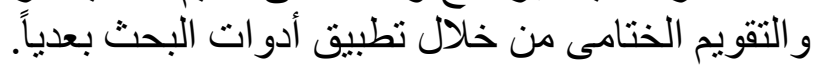
ضبط الوحدة: للتأكد من صلاحية الوحدة للتطبيق تم عرضها على مجموعة من المحكمين المتخصصين، وذللك بهدف التحقق من سلامة تصميم الوحدة ومناسبة محتو اه

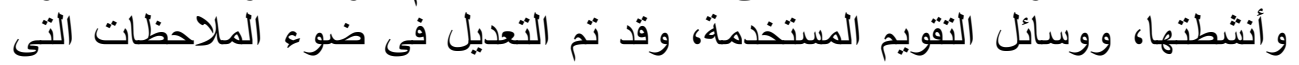


أبدها السادة المحكمين، وبهذا أصبحت الوحدة صالحة للتطبيق على تلاميذ الصف

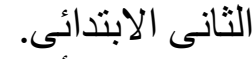

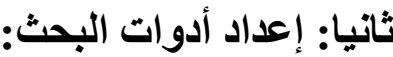
1 - الاختبار المفاهيم الرياضية:

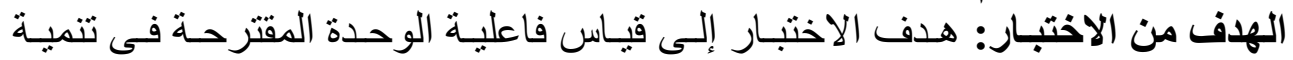

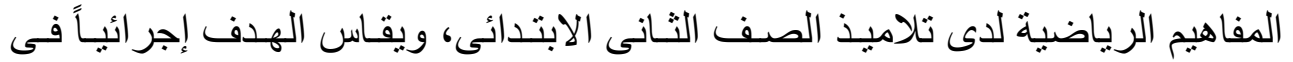

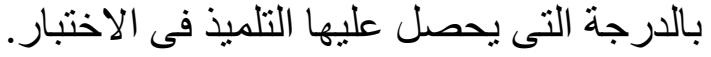

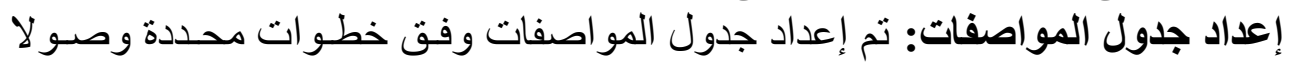
جدول (ז): جدول مواصفات اختبار المفاهيم الرياضية

\begin{tabular}{|c|c|c|c|c|}
\hline عدد الأسئلة & التطبيق & فهم & تنكر & لالأهداف \\
\hline$\varepsilon$ & 1 & r & 1 & الدرس الأول \\
\hline$r$ & 1 & 1 & . & الارس الثانى \\
\hline 1 & . & 1 & . & الارس الثالث \\
\hline$r$ & 1 & 1 & 1 & الارس الرابع \\
\hline$r$ & 1 & 1 & 1 & الدارس الخامس \\
\hline r & . & 1 & 1 & الدرس السادس \\
\hline 10 & $\varepsilon$ & $\mathrm{v}$ & $\varepsilon$ & عدد الأسئلة \\
\hline
\end{tabular}

تم صياغة مفردات الاختبار فى صورة خمس أسئلة؛ بحيث يتكون كل سـؤ ال مـن

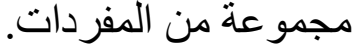
تصميم نظام لتقدير درجات الاختبار: تم اتباع النظام التالى فى توزيع الدارجات التات على التى

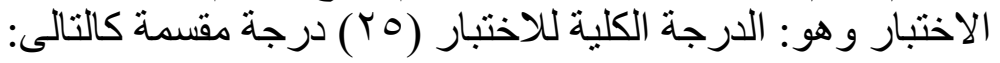
- - د درجتان للسؤال (الأول).

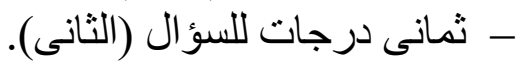
- ست درجات للسؤ ال (الثالث). - مثلاث درجات للسؤ ال (الرابع). - مت ست درجات للسؤ ال (الثالث).

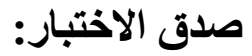
تم عرض الاختبار على مجمو عة من المحكمين لتعرف آر اءهم من حيث: - ـ شمول الاختبار لمحتوى الوحدة. 
- مدى مناسبة الأسئلة لمستوى التلاميذ.

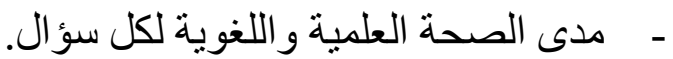

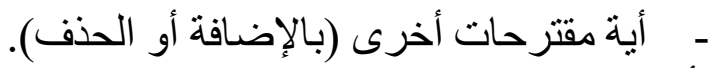

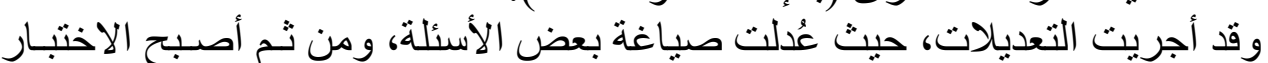

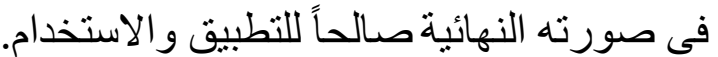

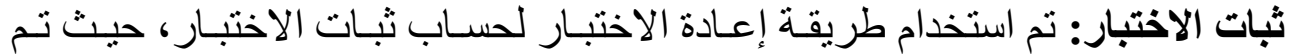

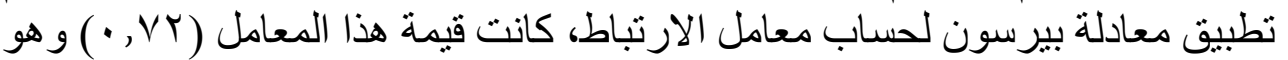

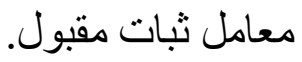

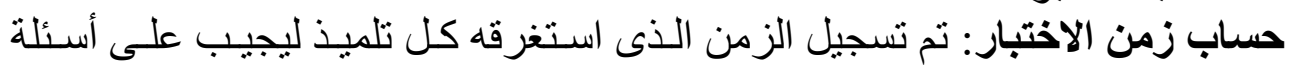

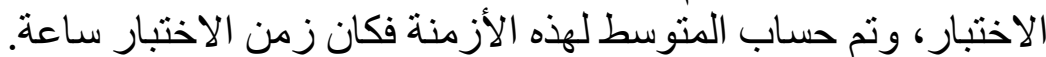

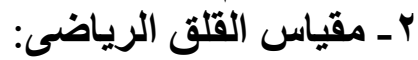

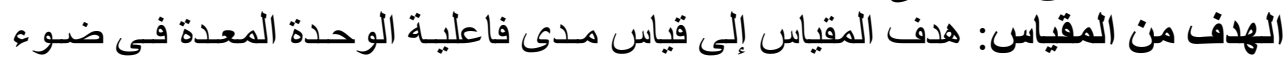

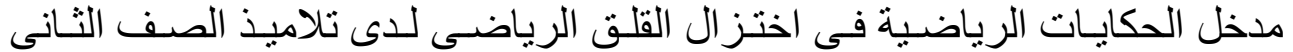

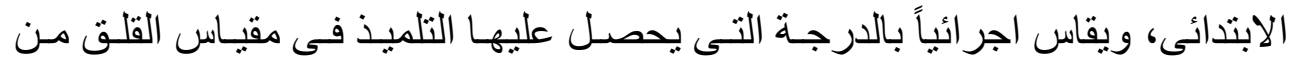

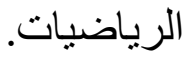

صياغة مفردات المقياس:

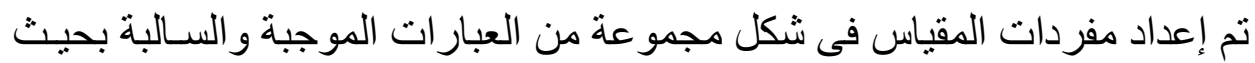

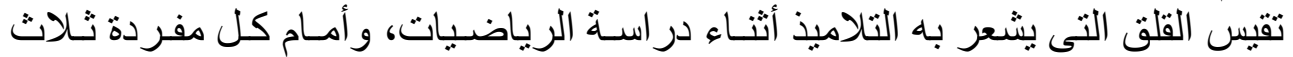

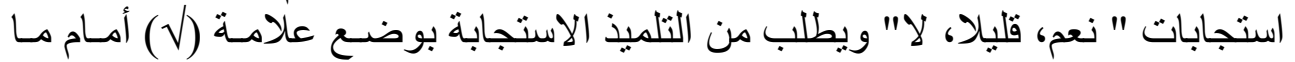

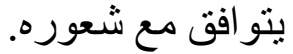
تقدير نظام الدرجات للمقياس:

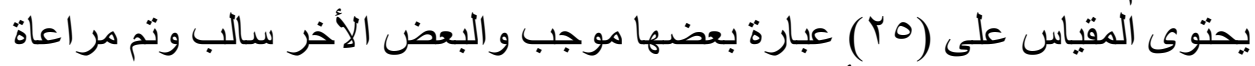
ذلك فى تقدير الدرجات، وقد أعطبي الدرجات كما يلى:

\begin{tabular}{|c|c|c|c|}
\hline$y$ & قليلا & نعم & \\
\hline$r$ & $r$ & 1 & لعبارات الموجبة \\
\hline 1 & $r$ & $r$ & العبارات السالبة \\
\hline
\end{tabular}

وبذلك تكون الدرجة الكلية العظمى لهذا الجزء (Y0) درجة، بينما الدرجة الصـغرى

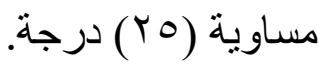
جدول (با): أرقام العبارات الموجبة والسالبة لمقياس القلق الرياضى

\begin{tabular}{|c|c|}
\hline العبارات اللسالبة & العبارات الموجبة \\
\hline $\begin{array}{c}611617,6) \leqslant 6960 \\
r_{0}\left(r_{1}\right)\end{array}$ & 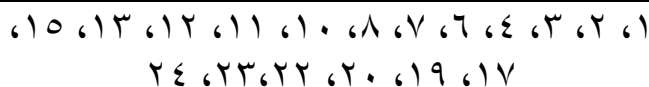 \\
\hline
\end{tabular}




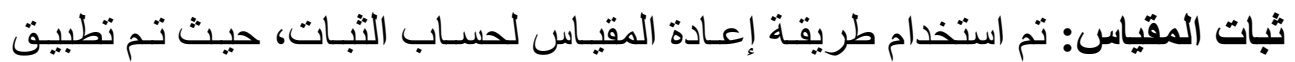

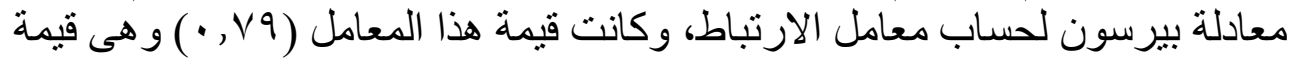

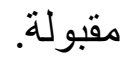
حساب زمن المقياس: تم تسجيل الزمن الذى استغرقه كل تلميذ ليجيب على المقيـاس،

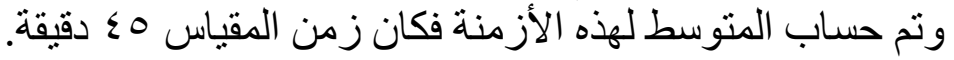

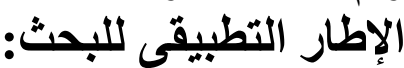
لتحقيق أهداف البحث الميدانية البحنة تم اتباع الإجر اءات الآتية:

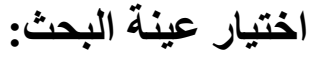

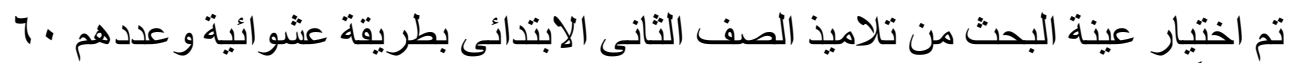

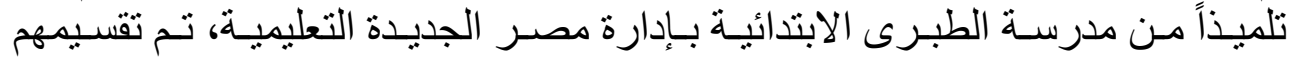

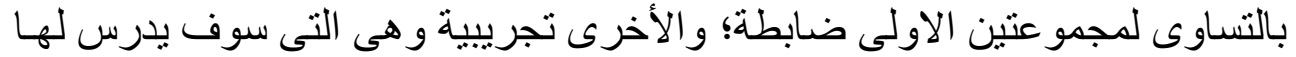

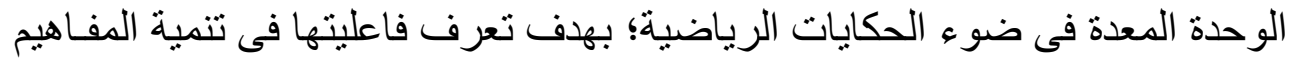

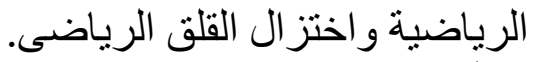

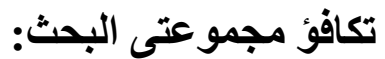

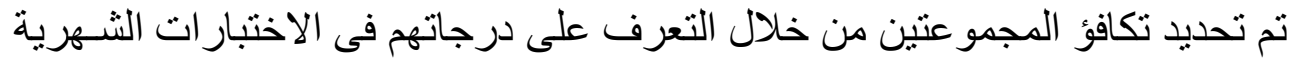

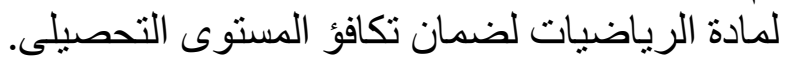

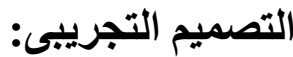
اتبع البحث التصميم التجريبى الذيى يعتمـد على المجمـو عتين التجريبيـة و الضـابطة:

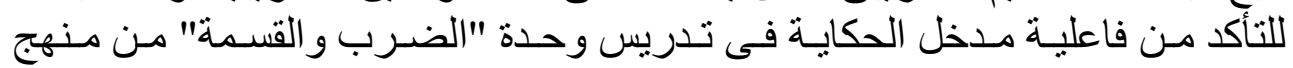

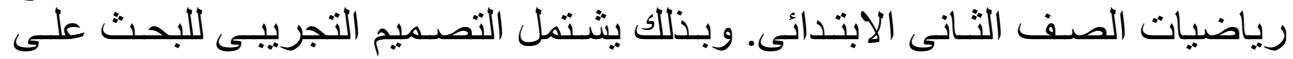

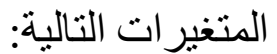
أ_المتغير المستقل: وحدة المعدة فى ضوء التهية الحكايات الرياضية.

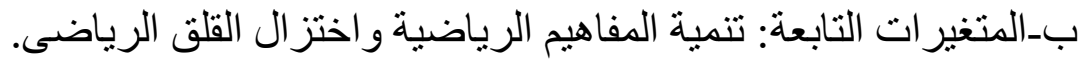

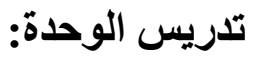

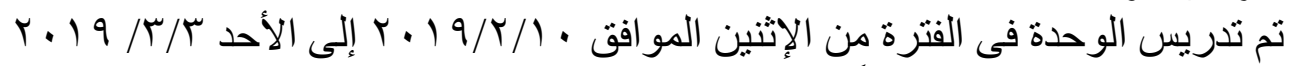
وذلإنك بو اقع حصنان أسبو عياً.

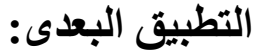

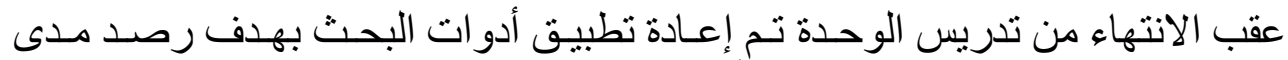

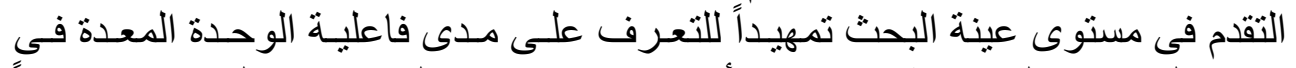

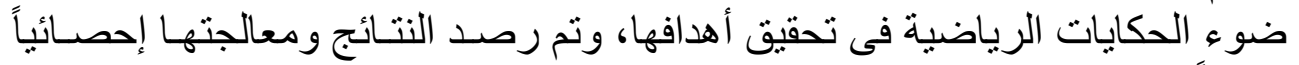
تمهيداً لتفسير ها وتقديم التوصيات و المقترحات فى ضو أريات النتائج التى تم التوصل إليها. 


\section{نتائج البحث وتفسير ها:}

تم رصد درجات التلاميذ قبل وبعد تدريس الوحدة، وبتحليل البيانات باستخدام برنامج

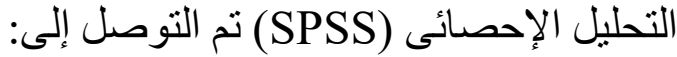

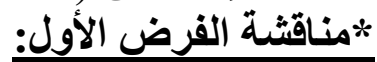
ينص الفرض الصفرى المناظر للفرض الأول على: لا يوجد فرق دال إحصـائيًا بـين

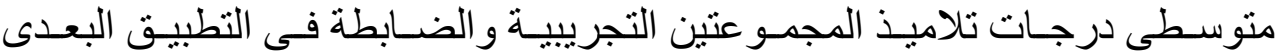
لاختبار المفاهيم الرياضية.

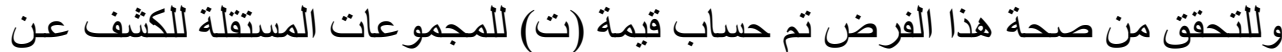

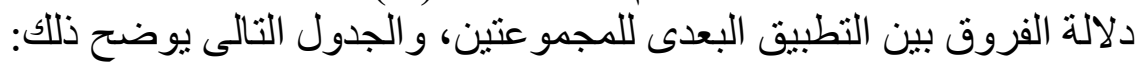

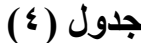

نتائج اختبار(ت) لالالة الفرق بين متوسطى درجات تلاميذ المجموعتين التجريبية والضابطة فى لإئي التطبيق البعدى لاختبار المفاهيم الرياضية لإمبية

\begin{tabular}{|c|c|c|c|c|c|c|c|}
\hline التأثنير & مستوي & قالمحسوبة (ت) & الحرية & المعيارى & الحسابى & العدد & التطبيق \\
\hline \multirow{2}{*}{ - A ^ } & \multirow{2}{*}{$\cdot, \cdot 1$} & \multirow{2}{*}{$1 \leqslant$, Y $_{0}$} & \multirow{2}{*}{ rq } & $r, Y Y$ & r & $r$. & التجريبية \\
\hline & & & & $r, \Lambda \varepsilon$ & ir & $r$. & الضابطة \\
\hline
\end{tabular}

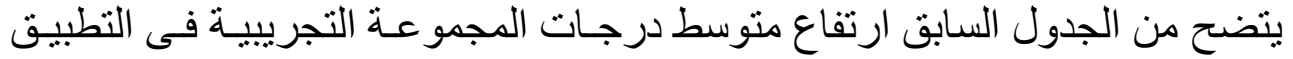

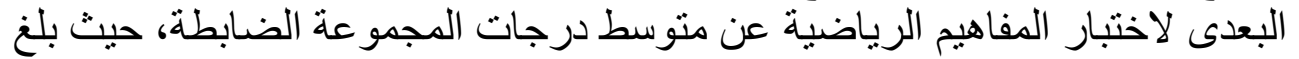

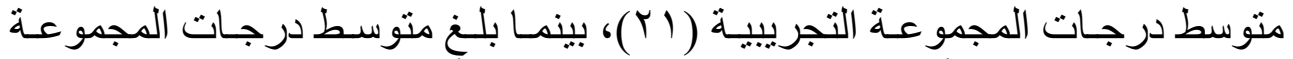

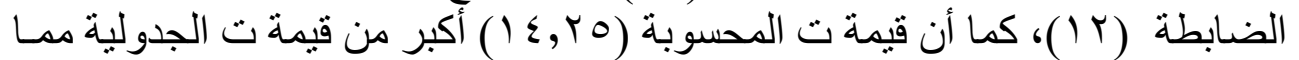

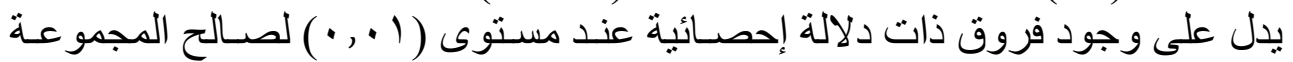

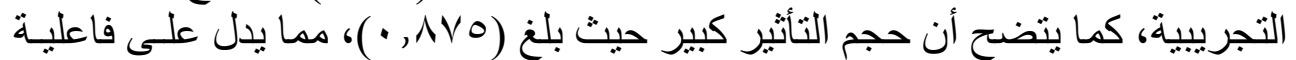

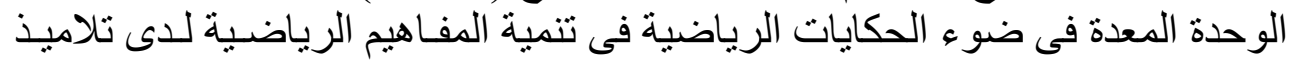

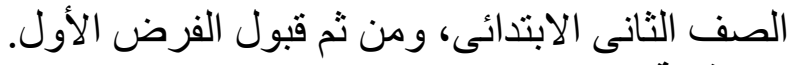

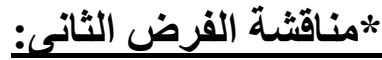

ينص الفرض الصفرى المناظر للفرض الثنانى على: لا يوجد فرق دال إحصـائيًا بـين متوسطى درجات تلاميذ المجمو عتين التجريبية والضابطة في التطبيق لإنيق البعدى لمقياس

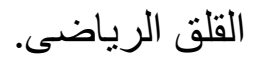

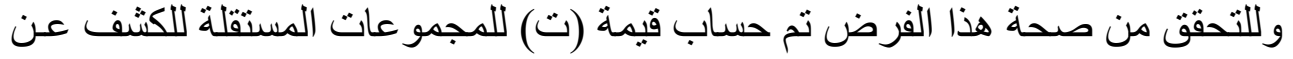
دلالة الفروق بين التطبيق البعدى للمجمو عتين، والجدول التالى يوضح ذلاب للك: 


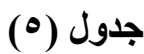

نتائج اختبار(ت) لالالة الفرق بين متوسطى درجات تلاميذ المجموعتين التجريبية والضابطة فى إنى

\begin{tabular}{|c|c|c|c|c|c|c|c|}
\hline التثأثير & مستوي & قالمحسوبة (ت) & درجة & المعيارى & الحسابى & العدد & التطبيق \\
\hline \multirow{2}{*}{ - ,qVr } & \multirow{2}{*}{$\cdot, .0$} & \multirow{2}{*}{$r_{1}, q$} & \multirow{2}{*}{ rq } & r,qY & $\checkmark \Lambda, r$ & $r$. & التجريبية \\
\hline & & & & $0, .9$ & $r \leqslant, 1$ & $r$. & الضابطة \\
\hline
\end{tabular}

يتضح من الجدول السـابق ارتفاع متوسط درجـات المجمو عـة التجريبيـة فـى التطبيتق

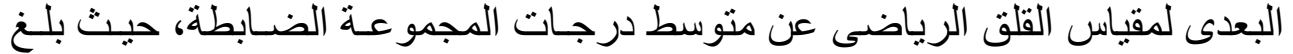

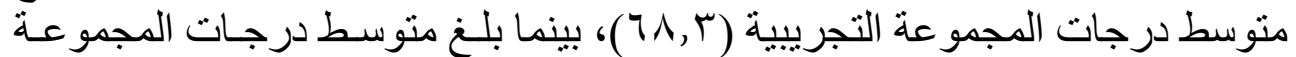

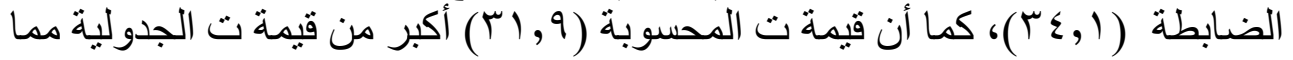

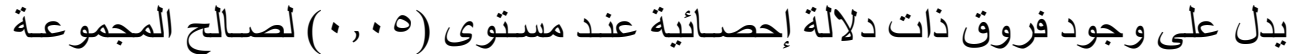

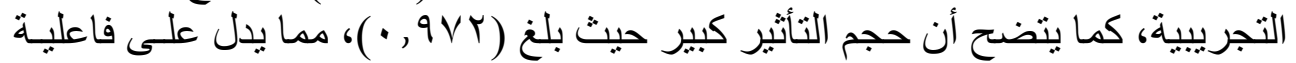

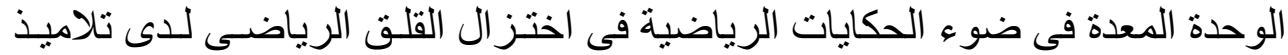

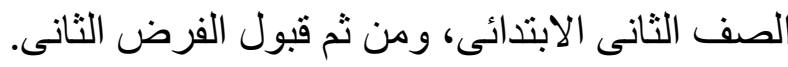
تفسير النتائج:

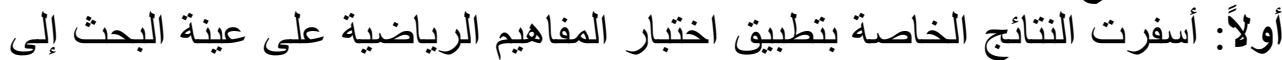
وجود فرق دال إحصائيا بين متوسطى درجات تلاميذ المجموعتين التجريبية

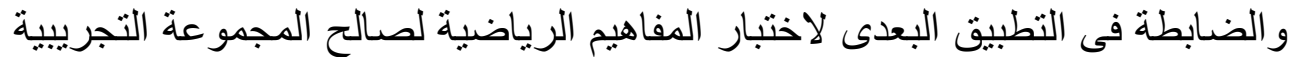

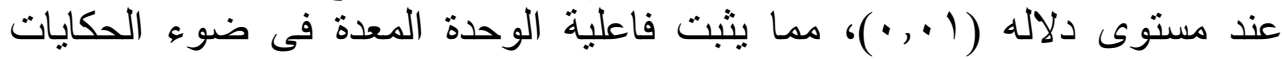
الرياضية فى تنمية المفاهيم الرياضية لدى تلاميذ عينة البحث، ويرجع ذلك إلى:

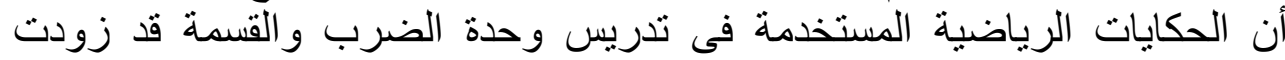
التلاميذ بالمعارف والخبرات الرياضية بصورة منكاملة اسهمت فئ تتمية مفهوم الضرب و القسمة لدى تلاميذ الصف الصفئ الثانى الابتدائى.

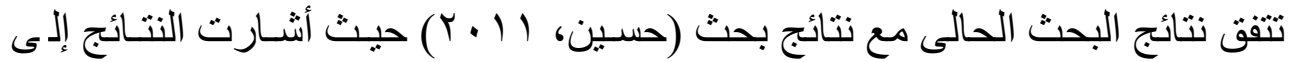

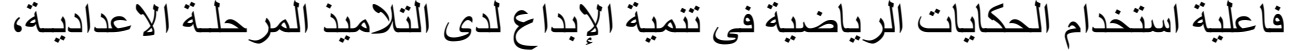

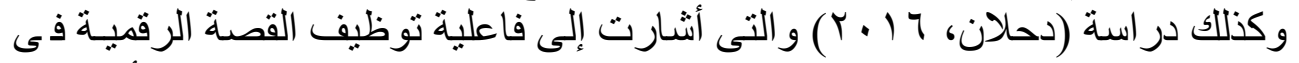

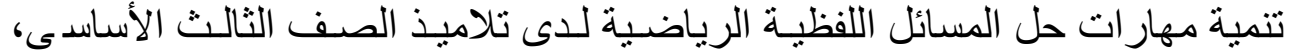

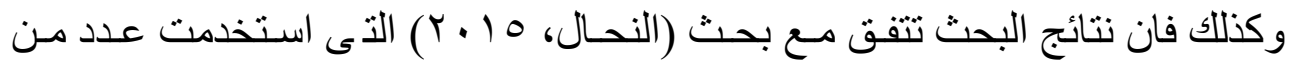

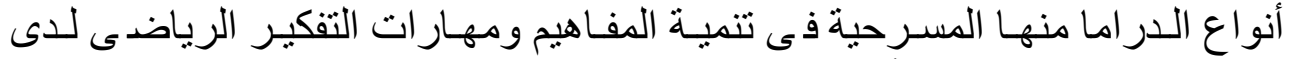
طالبات الصف السادس الأساسى. 
ثانياً: أسفرت النتائج الخاصة بتطبيق مقياس القلق الرياضى على عينة البحث إلى الى الى

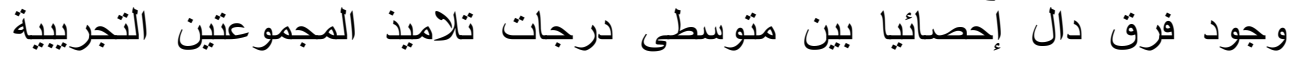

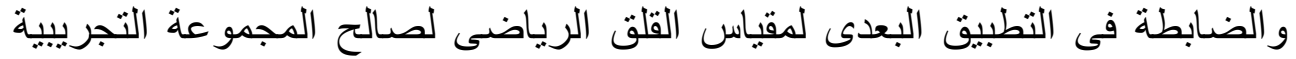

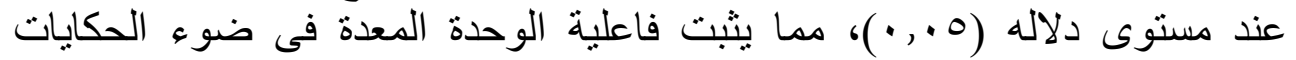

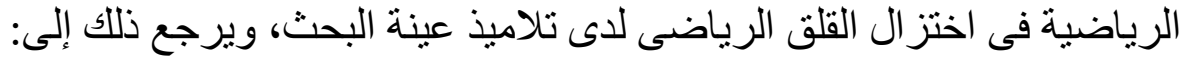

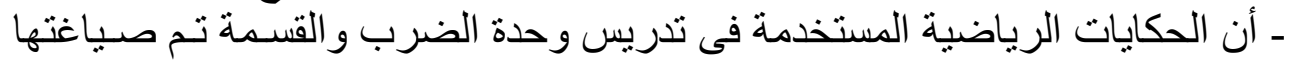
بشكل ممتع للتلاميذ يتو افر فيه عنصرى الإثارة و التشويق ومن ثم التغلب على جمود

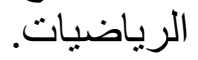

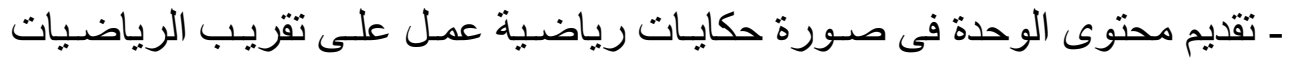

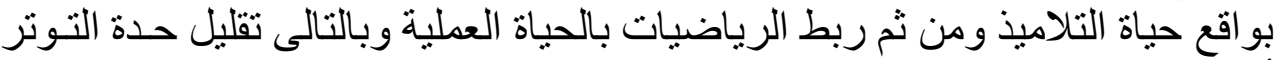

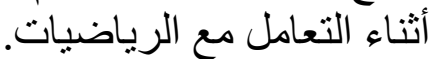

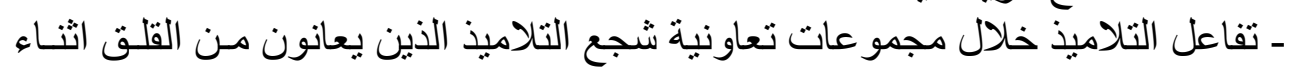

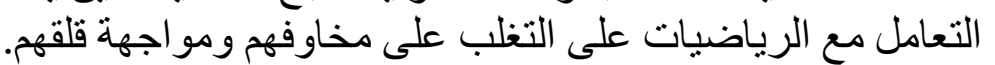

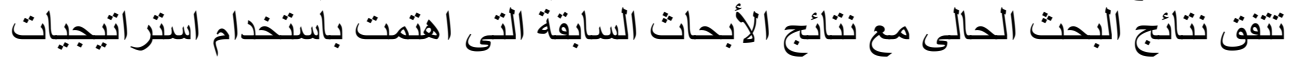

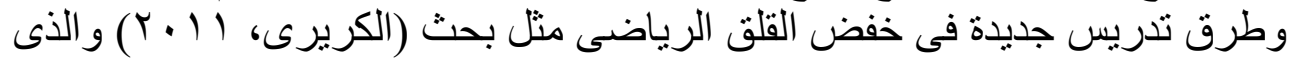

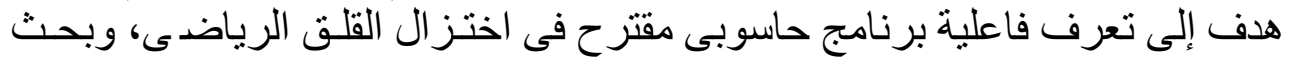

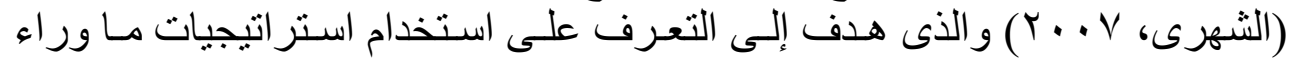

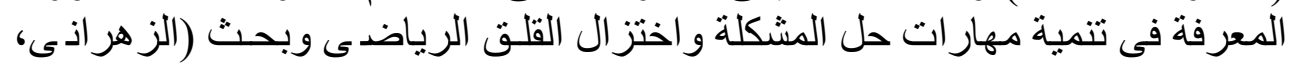

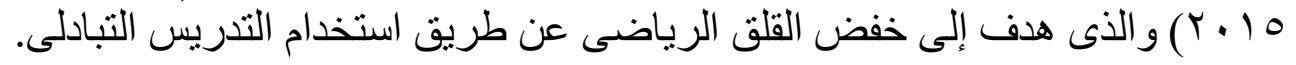

\section{توصيات البحث:}

فى ضوء النتائج التى توصل إلى إليها البحث، يمكن تقديم مجمو عة من التوصيات:

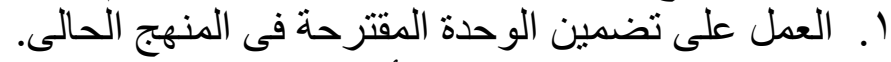

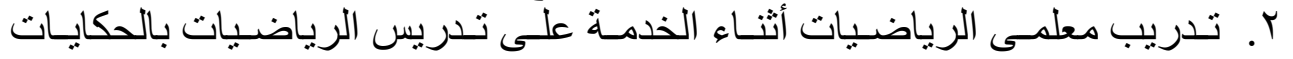

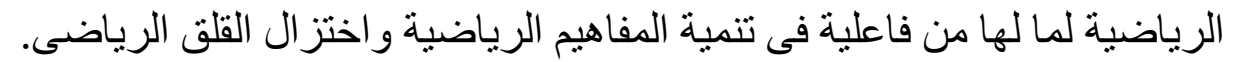

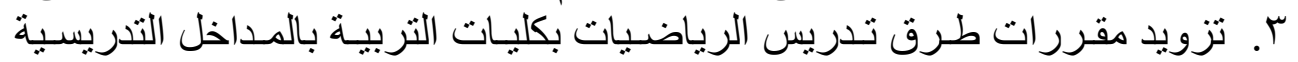

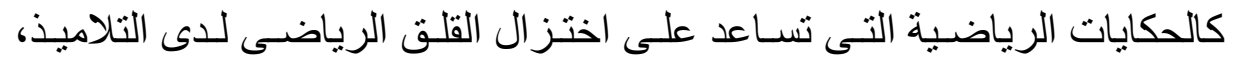

$$
\text { وتدريب الطلاب المعلمين عليها. }
$$

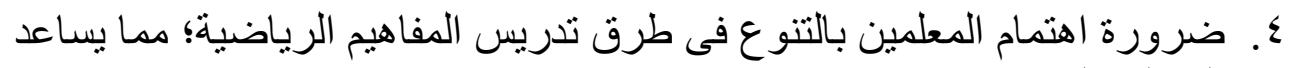

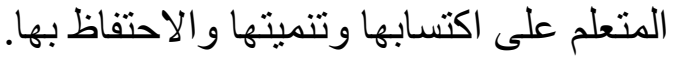

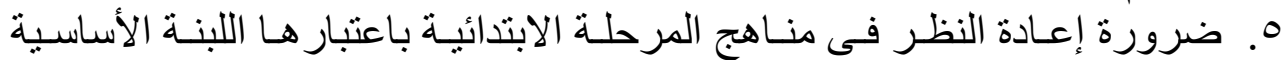

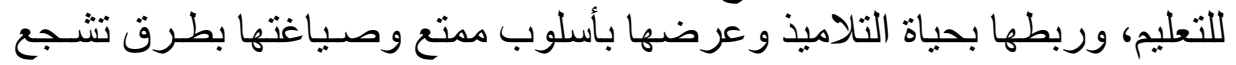
التلاميذ على تنمية حبهم للرياضيات ومن ثم اختز ال القلق الرياضى لديهم. 


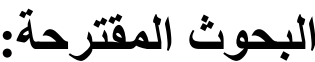

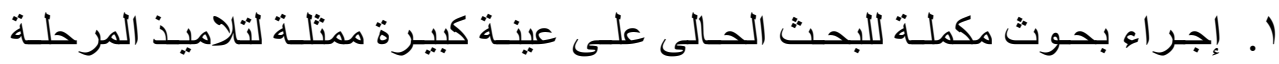
الابتدائية بحيث يمكن تعميم نتائجها.

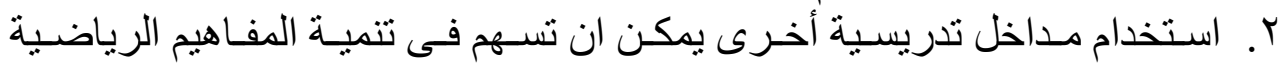

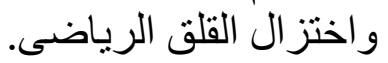

r.. در اسة أثر فاعلية الحكايات فى تقديم المقررات الدر اسية المختلفة لتنمية التحصيل

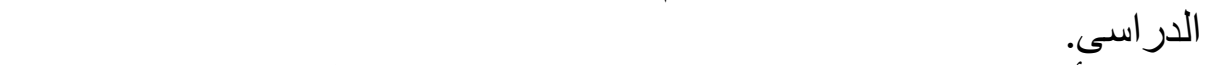

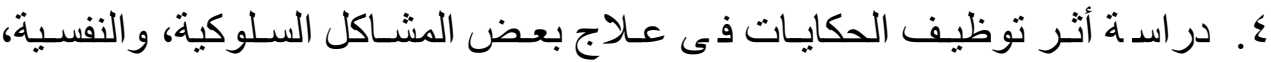
و و و الاجتماعية.

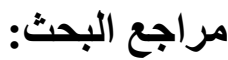

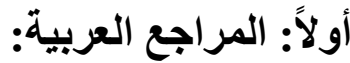

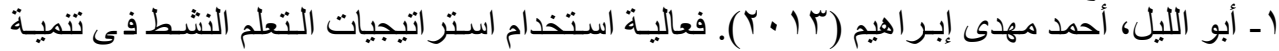

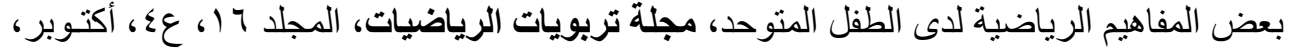

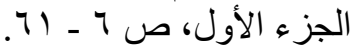

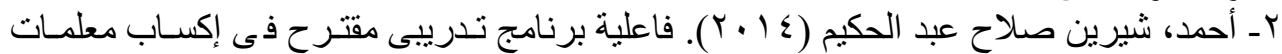

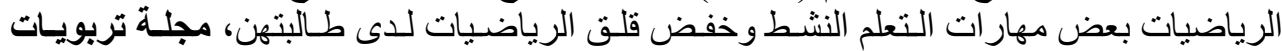

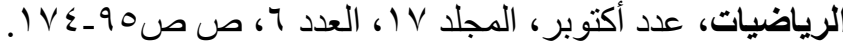

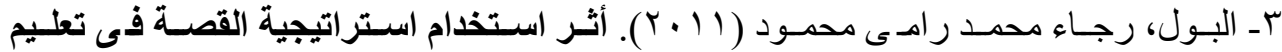

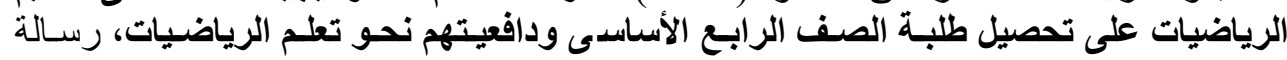

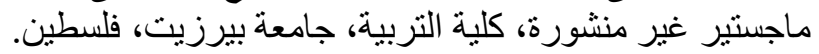

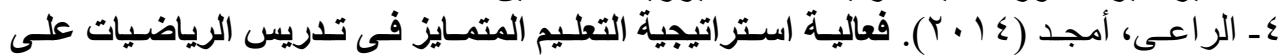

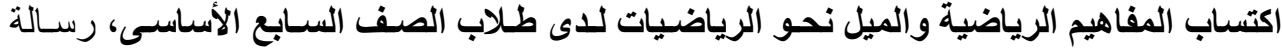

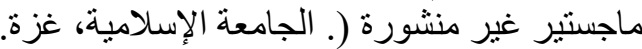

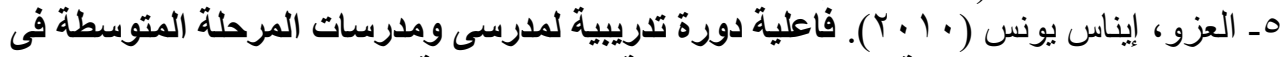

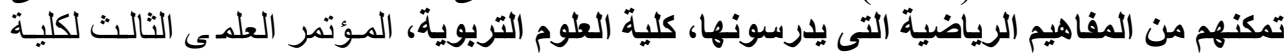

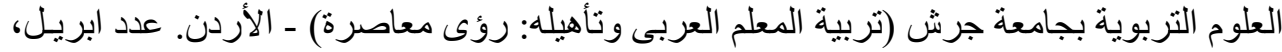

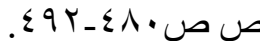

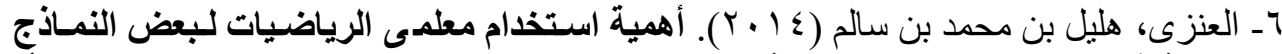

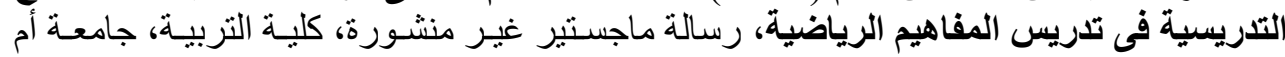

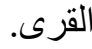

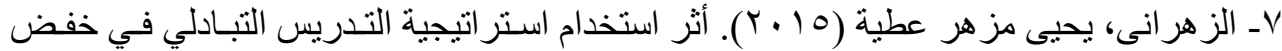

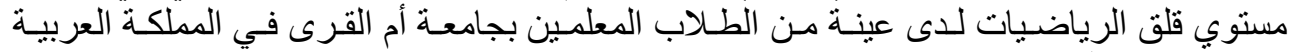

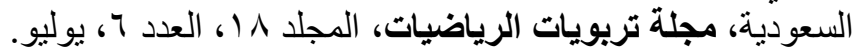




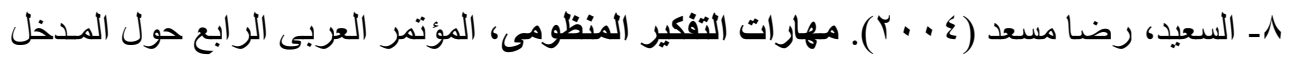

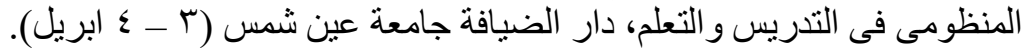

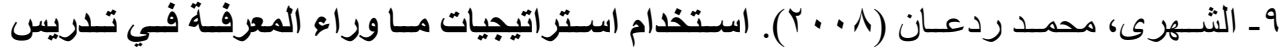

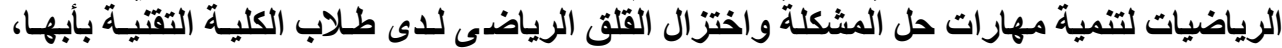

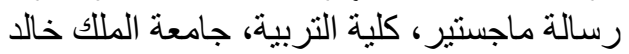

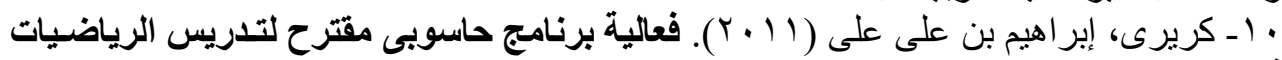

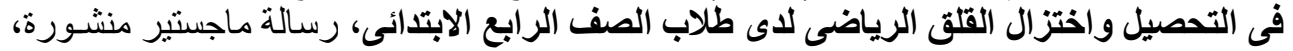
كلية التربية، جامعة الملك خالد، السعودية.

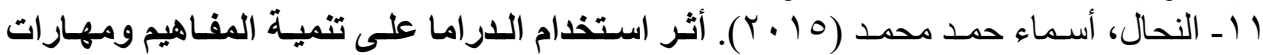

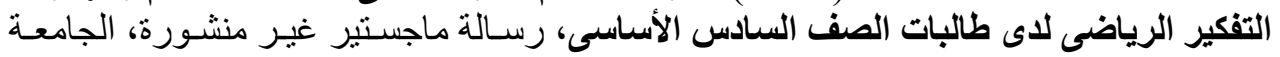

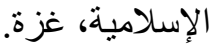

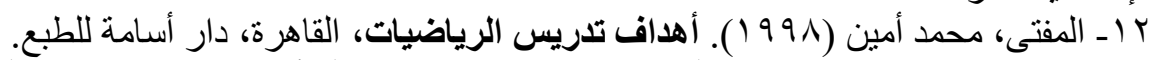

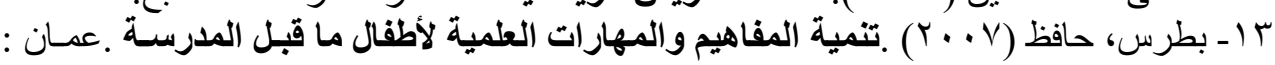

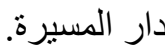

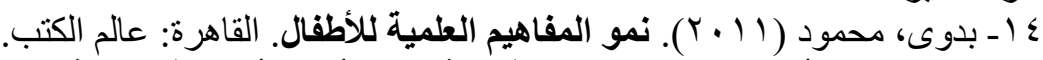

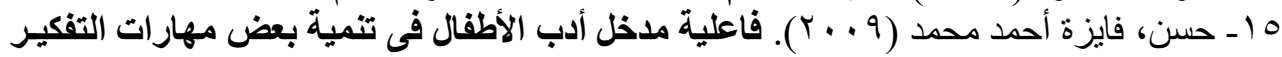

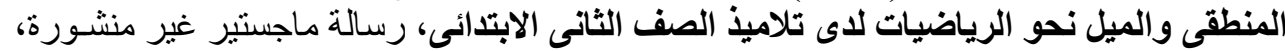

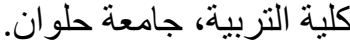

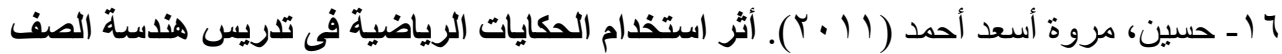

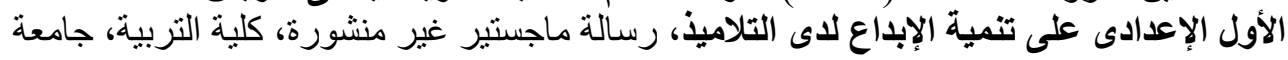

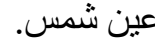

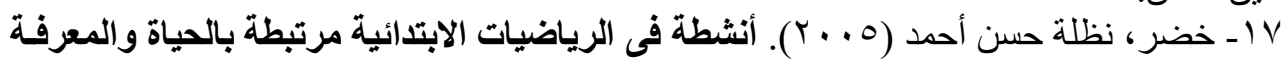

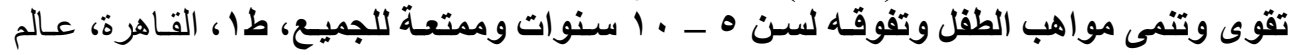

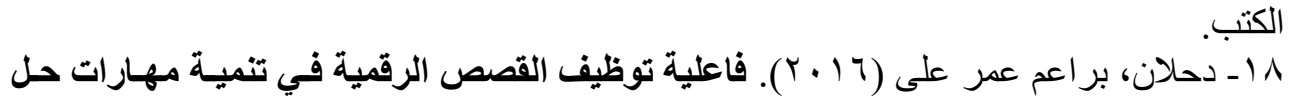

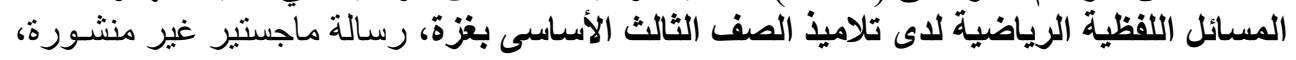

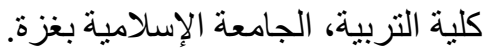

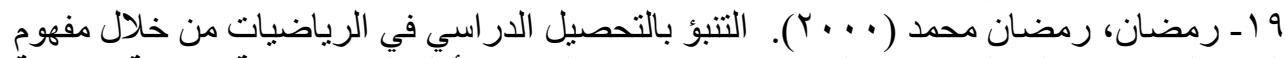

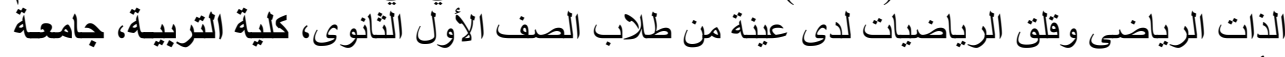

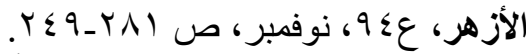

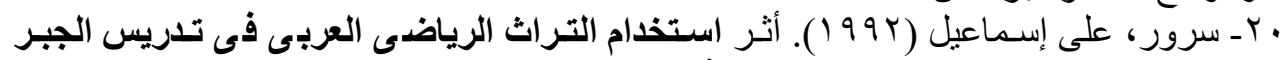

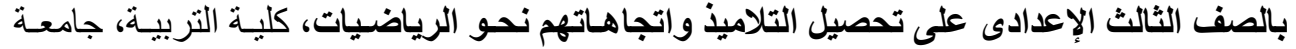
المنوفية.

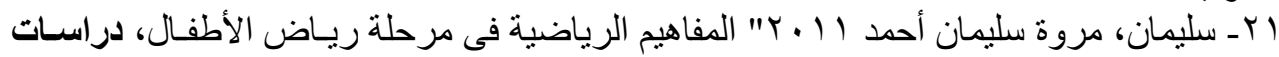

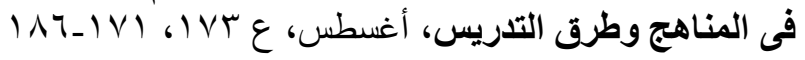




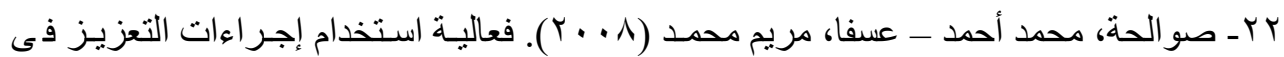

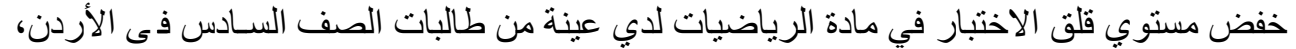

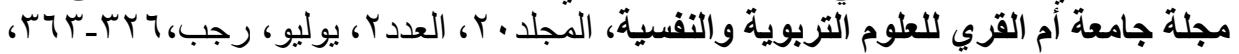

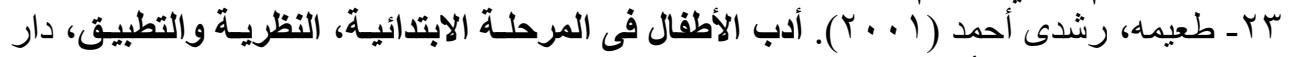

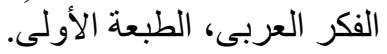

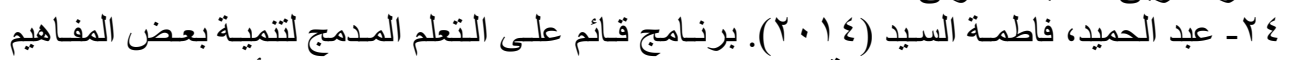

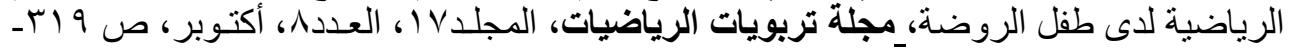
ए

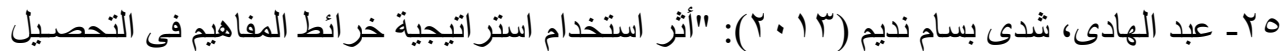

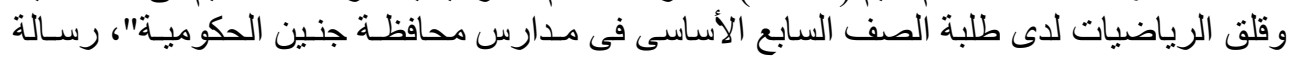

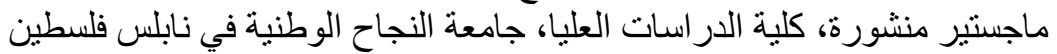

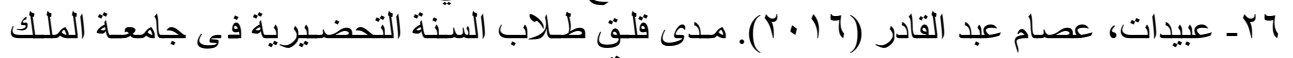

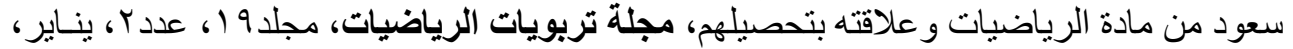

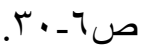

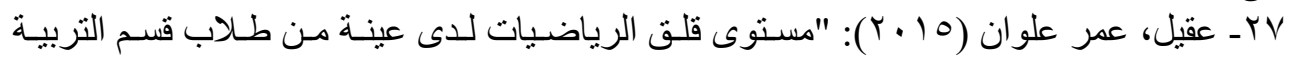

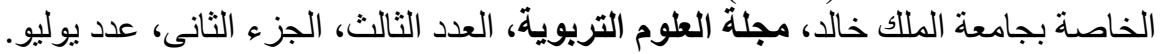

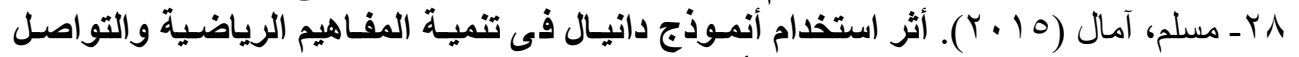

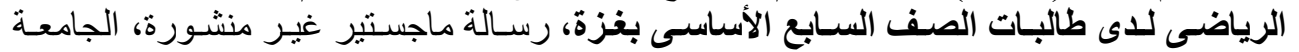

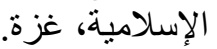

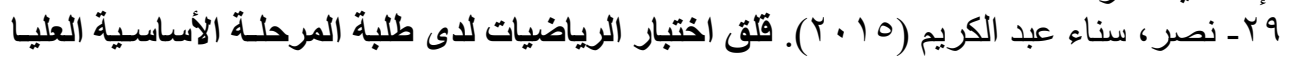

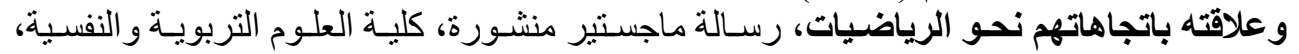
جامعة عمان العربية.

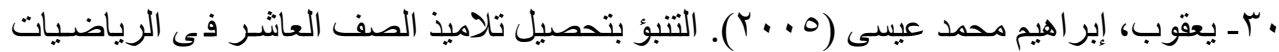

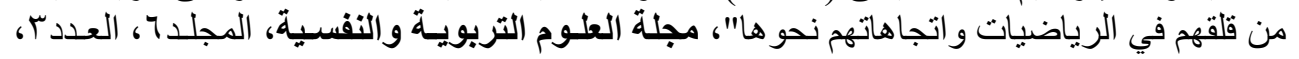

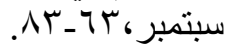

\section{ثانياً: المراجع الأجنبية:}

31. Angelo, F., \& Iliev, N. (2012). Teaching Mathematics to Young Children with Concrete and Virtual Manipulatives. USA: Bloomsburg University.

32. Bedore, B. (2004). Improve games for children and adults. Alameda, United States: Group West, Hunter House Inc.

33. Delaney, R.A (1990). An Anecdotal and Historical Approach to Mathematics Dissertation Abstract International Vol. 41, No. 2.

34. Vialva, Jessica Faith (2016). Mathematics anxiety within developmental mathematics classrooms " Teachers College, Columbia University. 
35. Hadjerrouit, S. (2015). Evaluating the Interactive Learning Tool Sum Real for Visualizing and Simulating Mathematical Concepts. Norway: University of Agder.

36. R.S.D. Thomas (2002). Mathematics and Narrative, The Mathematical intelligencer, No. 3, New York.

37. vitasari, et al, (2010). The Factors Affecting mathematics anxiety students, International Electronic Journal of Mathematics Education, 9 (1-2), pp. 25-37.

38. Young Hoan, ChoEmail (2015). Mathematical intuition and storytelling for meaningful learning "Disciplinary Intuitions and the Design of Learning Environments", pp. 155-168. 